\section{Pacific Northwest}

National Laboratory

Operated by Battelle for the

U.S. Department of Energy

\title{
Data Quality Objectives Summary Report - Designing a Groundwater Monitoring and Assessment Network for the 100-BC-5 and 100-FR-3 Operable Units
}

M.D. Sweeney

C.J. Chou

May 2003

Prepared for the U.S. Department of Energy under Contract DE-AC06-76RL01830 


\title{
DISCLAIMER
}

This report was prepared as an account of work sponsored by an agency of the United States Government. Reference herein to any specific commercial product, process, or service by trade name, trademark, manufacturer, or otherwise does not necessarily constitute or imply its endorsement, recommendation, or favoring by the United States Government or any agency thereof, or Battelle Memorial Institute.

\section{PACIFIC NORTHWEST NATIONAL LABORATORY \\ operated by \\ BATTELLE \\ for the}

UNITED STATES DEPARTMENT OF ENERGY

under Contract DE-AC06-76RL01830

Printed in the United States of America

Available to DOE and DOE contractors from the

Office of Scientific and Technical Information,

P.O. Box 62, Oak Ridge, TN 37831-0062;

ph: (865) 576-8401

fax: (865) 576-5728

email: reports@adonis.osti.gov

\author{
Available to the public from the National Technical Information Service, \\ U.S. Department of Commerce, 5285 Port Royal Rd., Springfield, VA 22161 \\ ph: (800) 553-6847 \\ fax: (703) 605-6900 \\ email: orders@ntis.fedworld.gov \\ online ordering: http://www.ntis.gov/ordering.htm
}

This document was printed on recycled paper. 


\title{
Data Quality Objectives Summary Report - Designing a Groundwater Monitoring and Assessment Network for the 100-BC-5 and 100-FR-3 Operable Units
}

\author{
M. D. Sweeney \\ C. J. Chou
}

May 2003

Prepared for

the U.S. Department of Energy

under Contract DE-AC06-76RL01830

Pacific Northwest National Laboratory

Richland, Washington 99352 


\section{Summary}

The 100-BC-5 and 100-FR-3 Operable Units are defined for groundwater beneath the $100-\mathrm{B} / \mathrm{C}$ and 100-F Areas, respectively. Each operable unit has undergone a limited field investigation and qualitative risk assessment as part of the Comprehensive Environmental Response, Compensation, and Liability Act of 1980 (CERCLA) remedial investigation process. Although decisions have been made to perform active remediation of contaminant sources, no decision has yet been made concerning remedial actions for groundwater at either operable unit. During this interim period, groundwater monitoring has been conducted in accordance with groundwater sampling and analysis plan for the 100-BC-5 Operable Unit (Sweeney 2002a) and 100-FR-3 Operable Unit (Sweeney 2002b) under Federal Facility Agreement and Consent Order (TPA) change control agreements between the U.S. Department of Energy (DOE) and U.S. Environmental Protection Agency (EPA). This report is the culmination of the decision process that will guide future data acquisition at these two operable units. The data gathered will be used to develop future closure decisions, leading ultimately toward a record of decision for the 100-BC-5 and 100-FR-3 Operable Units. Detailed background information that includes facility description, groundwater flow directions, monitoring network and monitoring constituents, constituents of potential concern, summary of groundwater contamination levels, sources of groundwater contamination, and contaminant distribution maps and trend charts is presented in Appendix.

The Data Quality Objectives (DQO) process, as described by EPA (EPA 1994), has been used to update the groundwater sampling and analysis schedules to reflect new information since the TPA agreement schedules were developed, and to reflect changing conditions at each operable unit as a consequence of surface-operable unit remedial actions. The product of this combined DQO process will be a separate sampling and analysis plan (SAP) for each of the operable units. The SAPs will be submitted to EPA by DOE and, when approved, will become part of the Administrative Record for these units, and will supercede the previous plans and TPA change control agreements. 


\section{Contents}

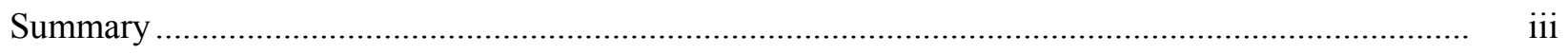

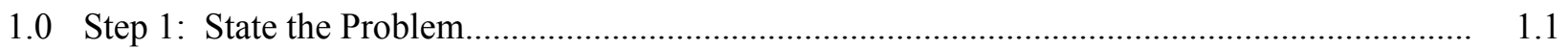

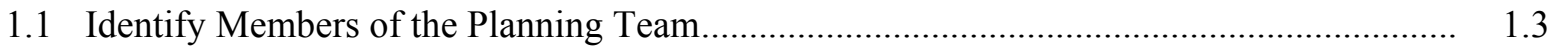

1.2 Develop the Conceptual Site Model.......................................................................... 1.3

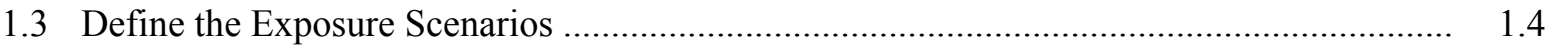

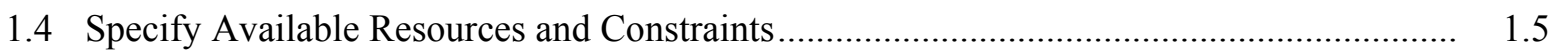

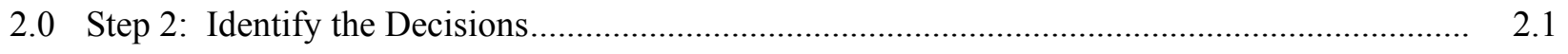

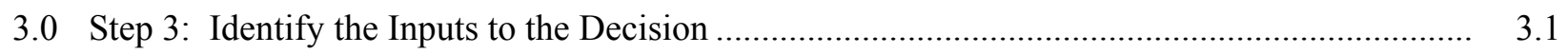

3.1 Information Required to Resolve Decision Statements................................................ 3.1

3.1.1 Basis for Setting the Action Level .................................................................... 3.2

3.1.2 Computational and Analytical Method ............................................................. 3.2

3.1.3 Analytical Performance Requirements......................................................... 3.3

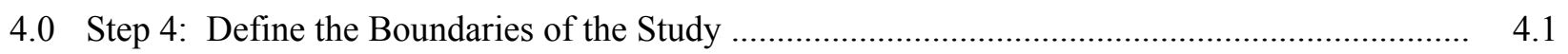

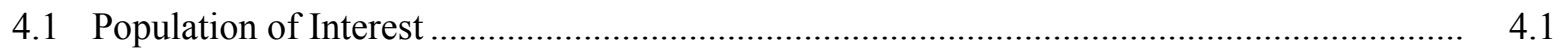

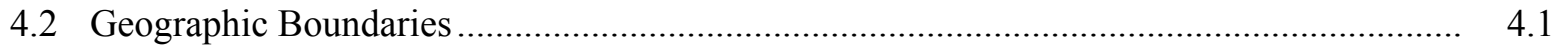

4.2.1 Zones with Homogeneous Characteristics ............................................................ 4.3

4.2.2 Temporal Boundaries .................................................................................. 4.3

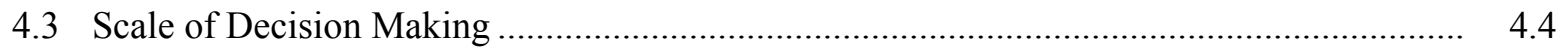

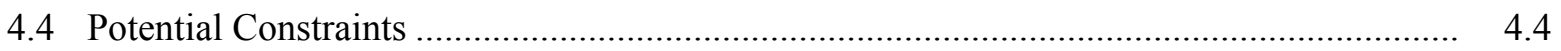

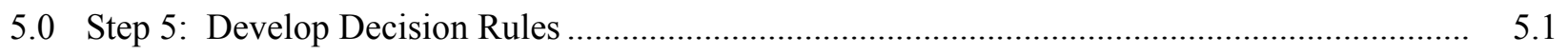

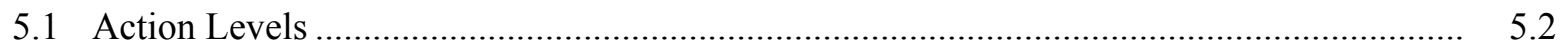

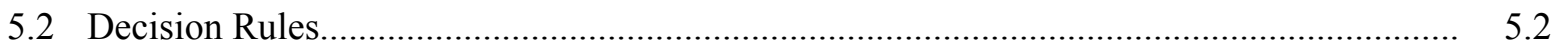

6.0 Step 6: Specify Tolerable Limits on Decision Errors ...................................................... 6.1 


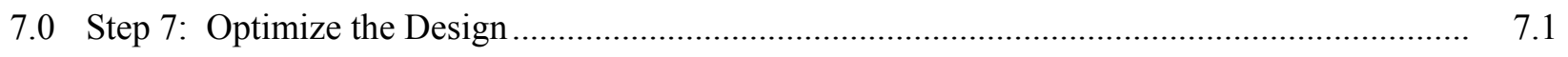

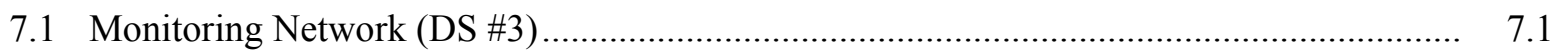

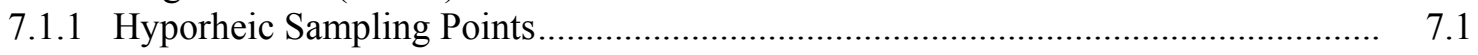

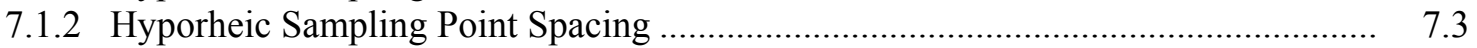

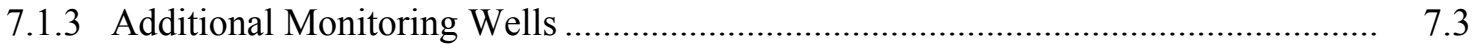

7.2 Seasonal Variability in Monitoring Wells Due to Water Level Changes (DS \#1).............. 7.4

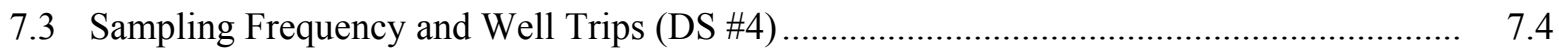

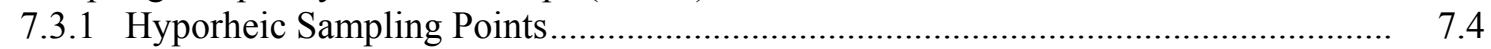

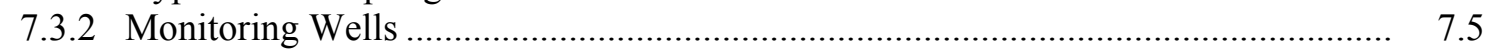

7.4 Constituent List, Sampling Constraints, and Analytical Alternatives (DS \#2) …............... 7.5

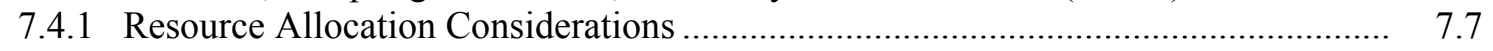

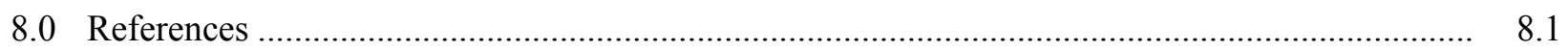

Appendix - 100-BC-5 and 100-FR-3 Data Quality Objectives …............................................. A.1

\section{Figures}

1.1 Conceptual Model for the 100-BC-5 and 100-FR-3 Operable Units ........................................ 1.4

4.1 Geographical Boundaries for the 100-B/C and 100-F Areas .......................................... 4.2

\section{Tables}

1.1 Data Quality Objective Team Members.........................................................................

1.2 Data Quality Objective Key Decision Makers ................................................................. 1.4

2.1 Summary of Data Quality Objective Step 2 Information................................................ 2.1

3.1 Required Information and Reference Sources ........................................................... 3.1

3.2 Basis for Setting Action Level ................................................................................ 3.3

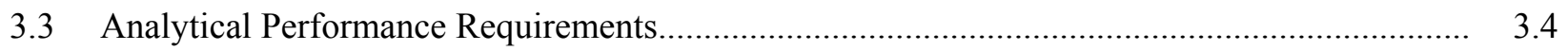

4.1 Characteristics that Define the Population of Interest.................................................. 
4.2 Geographic Boundaries of the Investigation ...................................................................

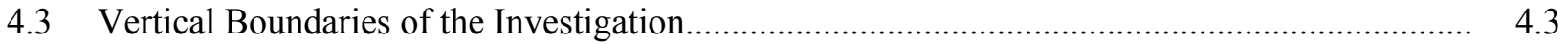

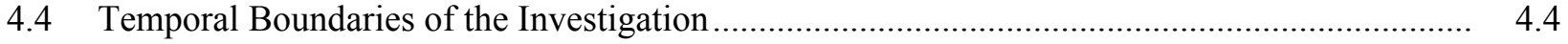

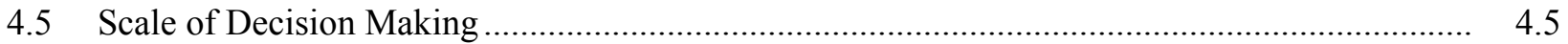

$5.1 \quad$ Inputs Needed to Develop Decision Rules................................................................... 5.1

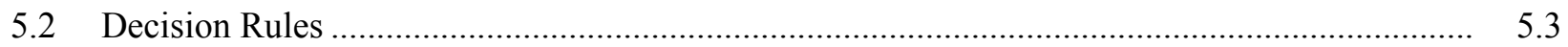

7.1 Recommended List of Constituents and Sample Frequency in Hyporheic Sampling Points and Groundwater Monitoring Wells of the 100-BC-5 and 100-FR-3 Operable Units 


\subsection{Step 1: State the Problem}

Groundwater monitoring activities began at 100-B/C and 100-F Areas with the start of reactor operations. Early assessments of groundwater impacts included the infiltration of radionuclides and their subsequent dispersion from cribs, trenches, and ditches near the individual reactors. The level of monitoring activity at both Areas was sparse and limited to a selected group of radiological contaminants and nitrate until the sites were added to the National Priority List in 1988.

Initiation of specific actions taken under the Comprehensive Environmental Response, Compensation, and Liability Act of 1980 (CERCLA) included the creation of the two groundwater operable units covered under this Data Quality Objective (DQO) exercise, i.e., 100-BC-5 and 100-FR-3. Remedial action/feasibility studies, limited field investigations, and interim action groundwater monitoring have been conducted as remediation of surface waste sites progressed. These activities have evaluated exposure risks associated with chemical and radiological constituents that have the potential to contaminate groundwater.

The primary objective of this DQO exercise is to establish a foundation for a sampling and analysis strategy that will bridge the gap between data obtained from earlier investigations and the information required to support future remedial action decisions. The new information contributes to the basis for decisions guiding the remediation methods, closure/compliance monitoring requirements, and developing records of decision for the 100-BC-5 and 100-FR-3 Operable Units. Step 1 of the DQO process, as described by the U.S. Environmental Protection Agency (EPA) (EPA 1994) summarizes the contamination problem, identifies the planning team, develops a conceptual site model, identifies exposure scenarios, and determines the resources available for the DQO study.

The vadose zone and groundwater underlying the 100-B/C and 100-F Areas have been contaminated by past disposal of liquid effluents that were primarily associated with reactor operations. The level of contamination in the environment has generally decreased since reactor operations ceased in the mid1960s as a result of (a) removal of contaminated soils at liquid waste disposal sites and along pipeline routes and (b) natural attenuation processes, such as radiological decay and dispersion by groundwater movement. Residual amounts of contaminants remain in the vadose zone and groundwater. The principal constituents of interest with respect to groundwater conditions are chemical constituents (chromium, nitrate, and trichloroethene) and radionuclides (strontium-90, tritium, and uranium; see Appendix). Some contaminant sources exist upgradient of the operable units and may contribute to the level of contamination.

Existing groundwater monitoring wells do not provide complete coverage of the area potentially underlain by groundwater plumes created by past operations. However, the locations of waste site sources for contaminants and the pattern of groundwater movement are reasonably well known, and approximate limits for the extent of contamination have been established. Opportunities to monitor contaminants near the area of groundwater discharge to the Columbia River are provided by hyporheic sampling points (also known as "aquifer sampling tubes") installed at the shoreline and by riverbank 
seepage sites. Contaminant movement in the river environment (i.e., via river flow and entry into the food chain) is monitored under the Public Safety and Resource Protection Program, which complements the monitoring conducted by the Groundwater Monitoring Project (GWMP).

Uncertainty exists in interpreting concentration trends observed at some monitoring wells. These wells show considerable variability and some of this variability is not readily explained. Because of water table fluctuations created by river stage changes, and the possibility that contaminants may not be evenly distributed in the aquifer, the variability may not necessarily represent a significant change in the overall level of contamination (i.e., reduction in mass and/or volume of contaminant in the environment). With the impending records of decision (ROD) for these groundwater operable units likely to include a component involving natural attenuation, it becomes necessary to gather new field data that are appropriate for demonstrating the rate at which the level of contamination is changing. In addition to new field observations, some component of modeling may be included for this demonstration because of the need to (a) estimate conditions in areas not covered by monitoring wells and (b) predict future conditions. While such modeling is beyond the scope of this plan, the field data will be used in conjunction with any modeling to support future records of decision for the 100 Area operable units.

The U.S. Department of Energy (DOE) has commissioned a pilot project at the 100-B/C Area to develop a procedure for evaluating the risk posed by residual amounts of contaminants left in the environment following completion of remedial actions at surface waste sites and, potentially, of groundwater. Based on experience gained at 100-B/C Area, similar evaluations will be conducted at other groundwater operable units near the Columbia River. Primary information needs associated with these evaluations include the nature, concentrations, release locations, rates of release, and temporal trends of contaminants that are delivered to the river environment by groundwater movement.

The following data quality objectives analysis is focused on developing an efficient sampling and analysis protocol for collecting field and laboratory data to support evaluation of groundwater contamination conditions as described above. The outcome of the DQO analysis will help in preparing a revised sampling and analysis plan for each of these operable units. The revised plan, or modifications to the plan, will be in effect during the interim period between active remediation of surface waste sites and the point-in-time when a ROD for final action with regard to groundwater operable units is reached.

\section{Problem Statement Summary:}

- Following the surface remediation of identified waste sites, some contamination will remain in the vadose zone and groundwater underlying these reactor areas for an indefinite period of time.

- The technical basis for future ROD will require information on the level of contamination in the environment; natural processes acting to reduce the level; and the rate at which natural processes are reducing the level.

- Information on the nature, extent, and mobility of contamination near the Columbia River is a key element for evaluating impacts to the river ecosystem, protection of which is a stated goal for the DOE's environmental restoration program. 


\subsection{Identify Members of the Planning Team}

Individual members of the DQO team were carefully selected to participate in the seven-step DQO process based on their technical background. The key decision makers included representatives from DOE and EPA Region 10. The role of the key decision makers is to make final decisions related to the approach and objectives of the sampling design.

Tables 1.1 and 1.2 identify each of the individual members of the DQO team including key decision makers. These tables also identify the organization that each DQO team or key decision maker represents, as well as their technical area of expertise.

\subsection{Develop the Conceptual Site Model}

As noted in the problem statement, the sources of contaminants are assumed to be disposed at pastpractice burial grounds and liquid waste disposal sites associated with reactor operations. Some contaminant remains in the vadose zone, and aquifer from past-practice - large-volume discharges (e.g., some strontium-90 adsorbed on aquifer solids). Infiltration of natural precipitation is presumed to carry some of the residual mobile contaminants (post-surface cleanup conditions) through the vadose zone beneath the disposal sites to groundwater. Contaminants entering the aquifer from the vadose zone under current conditions should be near the top of the aquifer. Average or net groundwater flow direction is north at $100-\mathrm{B} / \mathrm{C}$ Area and east to southeast in the 100-F Area. Shifts in flow direction can occur during prolonged high river discharge periods.

Because of changes in river stage, water table fluctuations may cause the contaminant layer to rise and fall. In wells close to the river these changes occur daily in response to release of water from the Priest Rapids Dam. However, longer term trends or changes in water level occur as well. With fixed depth pump intakes, contaminant concentrations may change with variations in water level (Figure 1.1). Alternatively, close to the vadose zone sources, rising water levels may mobilize vadose zone contamination, resulting in subsequent increases in contaminant concentrations in groundwater.

Table 1.1. Data Quality Objective Team Members

\begin{tabular}{||l|c|l||}
\hline \multicolumn{1}{|c|}{ Name } & Organization & \multicolumn{1}{c||}{ Role and Responsibility } \\
\hline \hline Charissa Chou & PNNL $^{(\text {a) }}$ & Statistician \\
\hline Evan Dresel & PNNL & Hydrogeologist \\
\hline John Fruchter & PNNL & Groundwater Project Manager \\
\hline Mary Hartman & PNNL & Hydrogeologist \\
\hline Vernon Johnson & PNNL & Hydrochemist \\
\hline Stuart Luttrell & PNNL & Monitoring Task Manager \\
\hline Bob Peterson & PNNL & Hydrogeologist \\
\hline Mark Sweeney & PNNL & Hydrogeologist \\
\hline (a) Pacific Northwest National Laboratory, Richland, Washington. \\
\hline
\end{tabular}


Table 1.2. Data Quality Objective Key Decision Makers

\begin{tabular}{||l|l|l||}
\hline \multicolumn{1}{|c|}{ Name } & \multicolumn{1}{c|}{ Organization } & \multicolumn{1}{c|}{ Role and Responsibility } \\
\hline \hline Dennis Faulk & EPA $^{(a)}$ & EPA Region 10 Representative \\
\hline Marv Furman & DOE $^{(\text {b) }}$ & DOE/RL Representative \\
\hline (a) U.S. Environmental Protection Agency, Richland, Washington. \\
(b) U.S. Department of Energy, Richland, Washington. \\
\hline \hline
\end{tabular}

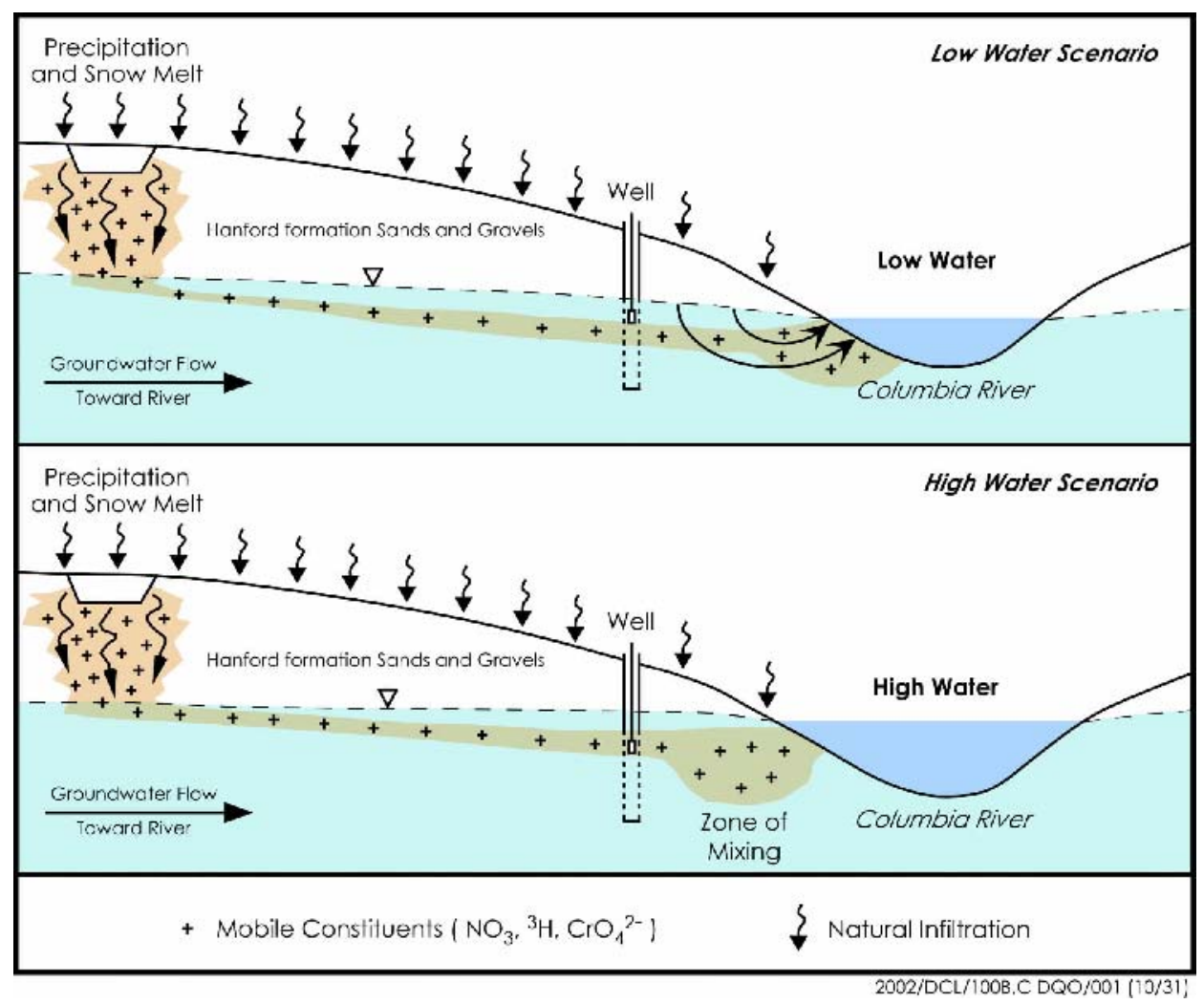

Figure 1.1. Conceptual Model for the 100-BC-5 and 100-FR-3 Operable Units

Mixing with ambient river water is expected in the stream bank storage zone near the shoreline, resulting in dilution of the contaminant plume prior to entering the free-flowing portion of the river. The extent of this mixing and dilution is unknown. Samples from riverbank springs and hyporheic sampling points provide some indication of the extent of such mixing.

\subsection{Define the Exposure Scenarios}

The most sensitive receptors are assumed to be the embryonic and emergent stages of salmonids (i.e., while the embryos are still in the spawning bed gravels). Salmon spawning beds occur in the river near the $100-\mathrm{B} / \mathrm{C}$ and $100-\mathrm{F}$ reactor areas. However, the redds observed at $100-\mathrm{B} / \mathrm{C}$ are not along the Hanford side of the river and only a few redds have been observed adjacent to the 100-F Area. Thus, the threat 
posed by environmental or ecological impacts of contaminants, such as hexavalent chromium, from the $100-\mathrm{B} / \mathrm{C}$ and $100-\mathrm{F}$ Areas is diminished because of mixing with river water and distance of the redds from the point of entry of the contaminant plumes in the river.

Hypothetical human exposures involve access to springs or bank seepage during low water periods and the near-shore zone where groundwater mixes with river water. Occasional visitors along the shoreline could drink from the springs, although most of these points of discharge are not very appealing as drinking water sources. Ingestion of edible portions of invertebrates from the shoreline (e.g., freshwater clams) is a possible exposure route. For purposes of this DQO, drinking water standards or maximum contaminant levels (MCLs) are assumed to be protective of both drinking water and tissue ingestion exposure routes. The drinking water standards are based on daily consumption of the contaminated source. A realistic exposure would involve only occasional access to such sources. Thus, use of the drinking water standards (or MCLs) that assume continuous daily intake are highly conservative relative to the hypothetical exposure scenario involving only occasional use of the riparian zone in the vicinity of the reactor areas. Anticipated risk assessments should provide more realistic applicable or relevant and appropriate requirements (ARARs) for the contaminants of concern (COCs); however, the existing drinking water standards will be used for the purposes of this DQO.

\subsection{Specify Available Resources and Constraints}

The budget for this DQO process is within the FY03 budget allocation. The scope included the development of a summary report presenting the results of a series of interviews held with technical and management representatives from DOE and EPA. These interviews determined the groundwater data quality objectives for the specific monitoring activities. Also included in this budget is the development of the sampling and analysis plans associated with the 100-BC-5 and 100-FR-3 operable units. The cost estimates supporting those budget allocations assume no dramatic changes to monitoring approach (i.e. extensive well drilling and installation program), or sampling and analysis plan revision. The timing constraints are: (1) DOE submits the DQO summary report that documents the results of the seven-step DQO process by the end of April 2003; and (2) develop a sampling and analysis plan (SAP) for each operable unit by the end of May 2003 for 100-BC-5 and June 2003 for 100-FR-3, based on agreements documented in the summary report. In the latter case, the SAP will have decisional drafts submitted for EPA review and approval. 


\subsection{Step 2: Identify the Decisions}

The purpose of DQO step 2 is to define the principal study questions (PSQ) that need to be answered to address the problem identified in DQO step 1 and the alternative actions (AA) that would result from the resolution of these questions. The PSQs and AAs are then combined into decision statements (DSs) that express a choice among alternative actions. Table 2.1 presents the task-specific PSQs, AAs, and resulting DSs. This table also provides a qualitative assessment of the severity of the consequences of taking an AA if it is incorrect. This assessment takes into consideration human health and the environment (e.g., ecological system), and political, economic, and legal ramifications. The severity of the consequences is expressed as low, moderate, or severe.

Table 2.1. $\quad$ Summary of Data Quality Objective Step 2 Information

\begin{tabular}{|c|c|c|c|}
\hline $\begin{array}{l}\mathrm{PSQ} / \mathrm{AA} \\
\quad \#\end{array}$ & Alternative Action & $\begin{array}{l}\text { Consequences of Implementing the Wrong } \\
\text { Alternative Action }\end{array}$ & $\begin{array}{c}\text { Severity of } \\
\text { Consequences } \\
\text { (Low/Moderate/Severe) }\end{array}$ \\
\hline \multicolumn{4}{|c|}{ PSQ $^{\#} 1$ Are representative samples of an aquifer with a fluctuating water table elevation being obtained? } \\
\hline $1-1$ & $\begin{array}{l}\text { No action (use existing } \\
\text { sampling method). }\end{array}$ & $\begin{array}{l}\text { The apparent observed downward } \\
\text { concentration trends may be due to an } \\
\text { artifact of river stage fluctuations and } \\
\text { sampling methods. It may be difficult to } \\
\text { demonstrate the rate at which the level of } \\
\text { contamination is changing (i.e., if natural } \\
\text { attenuation is working). }\end{array}$ & Moderate \\
\hline $1-2$ & $\begin{array}{l}\text { Select key wells and } \\
\text { determine vertical variability } \\
\text { (by positioning sample } \\
\text { pumps above and below the } \\
\text { existing fixed pump intake } \\
\text { depth). }\end{array}$ & $\begin{array}{l}\text { Unnecessary cost of sampling and } \\
\text { analyzing selected key wells at different } \\
\text { depth. }\end{array}$ & Low \\
\hline \multicolumn{4}{|c|}{ PSQ ${ }^{\#} 2$ Are constituents monitored necessary and sufficient? } \\
\hline $2-1$ & $\begin{array}{l}\text { No action (use existing } \\
\text { constituents per Sweeney } \\
2002 \mathrm{a} \text { and } 2002 \mathrm{~b} \text { ) }\end{array}$ & $\begin{array}{l}\text { Unnecessary cost of data } \\
\text { analysis/management, or list of } \\
\text { constituents of concern is incomplete. }\end{array}$ & Moderate \\
\hline $2-2$ & $\begin{array}{l}\text { Determine if a reduced list of } \\
\text { key indicators or surrogate } \\
\text { can be used. }\end{array}$ & May miss some constituents of concern & Moderate \\
\hline \multicolumn{4}{|c|}{$\begin{array}{l}\text { PSQ }{ }^{\#} 3 \text { Is the monitoring network adequate for purposes of tracking constituents that have potential } \\
\text { human and ecosystem impacts? }\end{array}$} \\
\hline $3-1$ & $\begin{array}{l}\text { No action (use existing } \\
\text { network per Sweeney } 2002 \mathrm{a} \\
\text { and } 2002 \mathrm{~b} \text { ) }\end{array}$ & $\begin{array}{l}\text { The constituent of concern contours may } \\
\text { not be clearly defined (plume extent not } \\
\text { well known). }\end{array}$ & Low/Moderate \\
\hline
\end{tabular}


Table 2.1. (contd)

\begin{tabular}{|c|c|c|c|}
\hline $\begin{array}{l}\mathrm{PSQ} / \mathrm{AA} \\
\quad \#\end{array}$ & Alternative Action & $\begin{array}{c}\text { Consequences of Implementing the Wrong } \\
\text { Alternative Action }\end{array}$ & $\begin{array}{c}\text { Severity of } \\
\text { Consequences } \\
\text { (Low/Moderate/Severe) }\end{array}$ \\
\hline $3-2$ & $\begin{array}{l}\text { Drill and install new } \\
\text { monitoring wells to } \\
\text { supplement existing well } \\
\text { network. }\end{array}$ & $\begin{array}{l}\text { Unnecessary cost of drilling new } \\
\text { monitoring wells. Unnecessary cost of } \\
\text { analyzing and managing data. }\end{array}$ & Moderate \\
\hline $3-3$ & $\begin{array}{l}\text { Determine if a larger array of } \\
\text { shoreline hyporheic } \\
\text { sampling points is a cost } \\
\text { effective alternative to } \\
\text { additional monitoring wells. }\end{array}$ & $\begin{array}{l}\text { Unnecessary cost of deploying more } \\
\text { shoreline hyporheic sampling points. } \\
\text { Unnecessary cost of analyzing and } \\
\text { managing data. }\end{array}$ & Low \\
\hline $3-4$ & $\begin{array}{l}\text { Determine if there is a need } \\
\text { to monitor the Ringold or } \\
\text { upper basalt confined } \\
\text { aquifers }\end{array}$ & $\begin{array}{l}\text { Unnecessary cost of drilling and } \\
\text { characterizing new monitoring wells. } \\
\text { Unnecessary cost of analyzing and } \\
\text { managing data }\end{array}$ & Moderate/Severe \\
\hline \multicolumn{4}{|c|}{ PSQ \#4 Does sampling frequency need to be revised for tracking plume movement? } \\
\hline $4-1$ & $\begin{array}{l}\text { No action (use existing } \\
\text { sampling frequency per } \\
\text { Sweeney } 2002 \mathrm{a} \text { and } 2002 \mathrm{~b} \text { ) }\end{array}$ & $\begin{array}{l}\text { Unnecessary cost of sampling, analyzing, } \\
\text { and managing data at locations where } \\
\text { constituents of concern are not detected or } \\
\text { detected at low concentrations. } \\
\text { Inadequate frequency at locations where } \\
\text { concentrations are increasing to a level of } \\
\text { concern or variability is high }\end{array}$ & Low \\
\hline $4-2$ & $\begin{array}{l}\text { Determine adequate sample } \\
\text { frequency of seeps and }\end{array}$ & $\begin{array}{l}\text { Unnecessary cost of analyzing and } \\
\text { managing data }\end{array}$ & Low \\
\hline $4-3$ & $\begin{array}{l}\text { fybes.mine the location of } \\
\text { increased sampling } \\
\text { downgradient of } \\
\text { representative waste site to } \\
\text { confirm that surface } \\
\text { remediation is protective of } \\
\text { the aquifer }\end{array}$ & $\begin{array}{l}\text { Unnecessary cost of analyzing and } \\
\text { managing data. }\end{array}$ & Low \\
\hline
\end{tabular}




\subsection{Step 3: Identify the Inputs to the Decision}

The purpose of DQO step 3 is to identify the information inputs needed to resolve each of the decision statements identified in DQO step 2. The data may already exist or may be derived from computational or sampling and analysis methods. Analytical performance requirements (e.g., detection limit requirement, precision, and accuracy) are also provided in this step for any new data that need to be collected.

\subsection{Information Required to Resolve Decision Statements}

Table 3.1 specifies the information required to resolve each of the decision statements identified in Table 2.1 and identifies whether the data to do so already exist. For existing data, the source references are listed.

Table 3.1. Required Information and Reference Sources

\begin{tabular}{|c|c|c|c|c|c|c|}
\hline DS \# & Variable & Required Data & $\begin{array}{l}\text { Do Data } \\
\text { Exist? } \\
(\mathrm{Y} / \mathrm{N})\end{array}$ & Source & $\begin{array}{l}\text { Sufficient } \\
\text { Quality? } \\
(\mathrm{Y} / \mathrm{N})\end{array}$ & $\begin{array}{l}\text { Additional } \\
\text { Information } \\
\text { Needed }(\mathrm{Y} / \mathrm{N})\end{array}$ \\
\hline 1 & $\begin{array}{l}\text { Vertical } \\
\text { variability }\end{array}$ & $\begin{array}{l}\text { Depth distributions of constituents } \\
\text { of interest at selected key well } \\
\text { locations. }\end{array}$ & $\mathrm{N}$ & Not available & $\mathrm{N}$ & Y \\
\hline 2 & $\begin{array}{l}\text { Constituents } \\
\text { of concern } \\
(\mathrm{COC})\end{array}$ & $\begin{array}{l}\text { Statistical summary of monitoring } \\
\text { data (e.g., the number of detected } \\
\text { analyses, variability, maximum, } \\
\text { etc.). Trend plots of COC } \\
\text { concentration versus time, contour } \\
\text { maps, and flow directions. Other } \\
\text { information need includes what are } \\
\text { the regulatory drivers and } \\
\text { concerns, and which standards } \\
\text { apply and where. }\end{array}$ & Y & $\begin{array}{l}\text { HEIS database } \\
\text { Hanford Site } \\
\text { Groundwater } \\
\text { Monitoring for Fiscal } \\
\text { Year 2001 (Hartman } \\
\text { et al. 2002) } \\
\text { Limited Field } \\
\text { Investigation for the } \\
\text { 100-BC-5 Operable } \\
\text { Unit (DOE/RL 1994a) } \\
\text { Limited Field } \\
\text { Investigation for the } \\
\text { 100-FR-3 Operable } \\
\text { Unit (DOE/RL 1994b) }\end{array}$ & $\mathrm{Y}$ & $\mathrm{N}$ \\
\hline $3 a$ & $\begin{array}{l}\text { Placement of } \\
\text { monitoring } \\
\text { wells }\end{array}$ & $\begin{array}{l}\text { Maps showing all potentially } \\
\text { useable groundwater wells within } \\
\text { the } 100-\mathrm{BC}-5,100-\mathrm{FR}-3 \text { OUs, and } \\
\text { nearby areas. Other information } \\
\text { includes well screen intervals, well } \\
\text { completion information, depth of } \\
\text { pump intakes, and spacing of } \\
\text { shoreline hyporheic sampling } \\
\text { points. }\end{array}$ & $\mathrm{Y}$ & $\begin{array}{l}\text { HWIS database and } \\
\text { project records } \\
\text { Hanford Site } \\
\text { Groundwater } \\
\text { Monitoring for Fiscal } \\
\text { Year 2001 (Hartman } \\
\text { et al. 2002) }\end{array}$ & $\mathrm{Y}$ & Maybe \\
\hline
\end{tabular}


Table 3.1. (contd)

\begin{tabular}{||c|l|l|c|l|c|c||}
\hline DS \# & Variable & \multicolumn{1}{|c|}{ Required Data } & $\begin{array}{c}\text { Do Data } \\
\text { Exist? } \\
\text { (Y/N) }\end{array}$ & \multicolumn{1}{|c|}{ Source } & $\begin{array}{c}\text { Sufficient } \\
\text { Quality? } \\
\text { (Y/N) }\end{array}$ & $\begin{array}{c}\text { Additional } \\
\text { Information } \\
\text { Needed (Y/N) }\end{array}$ \\
\hline \hline $3 \mathrm{~b}$ & $\begin{array}{l}\text { Properties of } \\
\text { Ringold or } \\
\text { upper basalt } \\
\text { confined } \\
\text { aquifers and } \\
\text { confining } \\
\text { units }\end{array}$ & $\begin{array}{l}\text { Hydrogeological characterization } \\
\text { and water quality data }\end{array}$ & $\begin{array}{c}\text { Y } \\
\text { limited }\end{array}$ & $\begin{array}{l}\text { Hydrochemistry and } \\
\text { Hydrogeologic } \\
\text { Conditions Within the } \\
\text { Hanford Upper Basalt } \\
\text { Confined Aquifer } \\
\text { System (Spane and } \\
\text { Webber 1995) }\end{array}$ & $\mathrm{Y}$ & $\mathrm{N}$ \\
\hline 4 & $\begin{array}{l}\text { Sampling } \\
\text { frequency }\end{array}$ & $\begin{array}{l}\text { Statistical summary of monitoring } \\
\text { data (e.g., the number of detected } \\
\text { analyses, variability, maximum, } \\
\text { etc.). Trend plots of COC } \\
\text { concentration versus time, contour } \\
\text { maps, monitoring data obtained } \\
\text { from seeps and tubes, and } \\
\text { contaminant(s) migration rate(s). }\end{array}$ & Y & $\begin{array}{l}\text { HEIS database } \\
\text { Hanford Site } \\
\text { Groundwater } \\
\text { Monitoring for Fiscal } \\
\text { Year 2001 (Hartman } \\
\text { et al. 2002) }\end{array}$ & $\mathrm{Y}$ & N \\
\hline \hline
\end{tabular}

\subsubsection{Basis for Setting the Action Level}

The action level is the threshold value that provides a criterion for choosing between alternative actions. Table 3.2 identifies the basis (i.e., regulatory threshold or risk-based) for establishing the action level for each of the constituents of potential concern (see Appendix). The numerical value for the action level is provided in Table 3.2. However, for this DQO, a numerical action level alone cannot always be used in deciding between alternative actions. Judgment and other qualitative considerations must also be used.

The basis for hexavalent chromium is WAC 173-201A-040, Toxic Substances, paragraph (C) and the criteria apply to "...all surface waters of the State of Washington for the protection of aquatic life." For hexavalent chromium, the criterion for acute toxicity is $15 \mu \mathrm{g} / \mathrm{L}$ and for chronic toxicity, it is $10 \mu \mathrm{g} / \mathrm{L}$ (Note: The equivalent EPA regulations use 16 and $11 \mu \mathrm{g} / \mathrm{L}$, respectively, for the same criteria). Also, an ARAR of $22 \mu \mathrm{g} / \mathrm{L}$ in near-river groundwater was established as a target cleanup concentration for the pump-and-treat operations addressing chromium at the 100-K, 100-D, and 100-H Areas (EPA 1996). It is based on the assumption that groundwater is diluted by an equal portion of river water prior to being discharged through the riverbed. That is, if groundwater approaching the river had a concentration of $22 \mu \mathrm{g} / \mathrm{L}$, it would be diluted to $11 \mu \mathrm{g} / \mathrm{L}$ (or lower) at the point of exposure in the riverbed.

\subsubsection{Computational and Analytical Method}

The evaluation of adequacy of the monitoring networks to resolve the decision statements for the 100-BC-5 and 100-FR-3 Operable Units will be undertaken on the basis of a combination of network design modeling and professional judgment. Depending on the outcome of this initial or scoping effort, geostatistical modeling may be used as well. 
Table 3.2. Basis for Setting Action Level

\begin{tabular}{|c|c|c|c|c|}
\hline DS \# & Monitoring Variable & Constituent $^{(\mathrm{a})}$ & Action Level & Basis for Setting Action Level \\
\hline \multirow[t]{12}{*}{1} & \multirow{5}{*}{$\begin{array}{l}\text { Concentration in } 100-B C-5 \\
\text { groundwater wells with depth }\end{array}$} & Strontium-90 & $8 \mathrm{pCi} / \mathrm{L}$ & http://www.epa.gov/safewater/mcl.html \\
\hline & & Tritium & $20,000 \mathrm{pCi} / \mathrm{L}$ & http://www.epa.gov/safewater/mcl.html \\
\hline & & $\begin{array}{l}\text { Chromium/ } \\
\text { Hexavalent } \\
\text { Chromium }\end{array}$ & $100 / 22 \mu \mathrm{g} / \mathrm{L}$ & $\begin{array}{l}\text { http://www.epa.gov/safewater/mcl.html } \\
\text { www.ecy.wa.gov/laws-rules } \\
\text { Ambient Water Quality Criteria Value } \\
\text { (WAC 173-201A-040) for chronic toxicity }\end{array}$ \\
\hline & & Aluminum $^{(\mathrm{b})}$ & $50 \mu \mathrm{g} / \mathrm{L}$ & http://www.epa.gov/safewater/mcl.html \\
\hline & & Iron $^{(b)}$ & $300 \mu \mathrm{g} / \mathrm{L}$ & http://www.epa.gov/safewater/mcl.html \\
\hline & \multirow{7}{*}{$\begin{array}{l}\text { Concentration in } 100-F R-3 \\
\text { groundwater wells with depth }\end{array}$} & Strontium-90 & $8 \mathrm{pCi} / \mathrm{L}$ & http://www.epa.gov/safewater/mcl.html \\
\hline & & Tritium & $20,000 \mathrm{pCi} / \mathrm{L}$ & http://www.epa.gov/safewater/mcl.html \\
\hline & & $\begin{array}{l}\text { Chromium/ } \\
\text { Hexavalent } \\
\text { Chromium }\end{array}$ & $100 / 22 \mu \mathrm{g} / \mathrm{L}$ & $\begin{array}{l}\text { http://www.epa.gov/safewater/mcl.html } \\
\text { www.ecy.wa.gov/laws-rules } \\
\text { Ambient Water Quality Criteria Value } \\
\text { (WAC 173-201A-040) for chronic toxicity }\end{array}$ \\
\hline & & Uranium & $30 \mu \mathrm{g} / \mathrm{L}$ & http://www.epa.gov/safewater/mcl.html \\
\hline & & Trichloroethene & $5 \mu \mathrm{g} / \mathrm{L}$ & http://www.epa.gov/safewater/mcl.html \\
\hline & & Nitrate $\left(\right.$ as $\left.\mathrm{NO}_{3}^{-}\right)$ & $45,000 \mu \mathrm{g} / \mathrm{L}$ & $\underline{\text { http://www.epa.gov/safewater/mcl.html }}$ \\
\hline & & Manganese $^{(\mathrm{b})}$ & $50 \mu \mathrm{g} / \mathrm{L}$ & http://www.epa.gov/safewater/mcl.html \\
\hline 2 & Concentration in groundwater & \multicolumn{2}{|l|}{ Same as DS \#1 } & Same as DS \#1 \\
\hline 3 & $\begin{array}{l}\text { Placement of monitoring } \\
\text { wells }\end{array}$ & \multicolumn{2}{|l|}{ N/A } & N/A \\
\hline 4 & Sample frequency & \multicolumn{2}{|l|}{ Same as DS \#1 } & Same as DS \#1 \\
\hline \multicolumn{5}{|c|}{$\begin{array}{l}\text { (a) These are constituents of potential concern as identified by limited field investigations conducted under CERCLA (see } \\
\text { Appendix). } \\
\text { (b) Secondary contaminant. }\end{array}$} \\
\hline
\end{tabular}

\subsubsection{Analytical Performance Requirements}

Analytical performance criteria for future groundwater sampling activities, resulting from the implementation of the final sampling design, are presented in Table 3.3. The analytical methods and precision/accuracy requirements shown in Table 3.3 are summarized from PNNL Quality Assurance Plan (PNNL 2000) and Hartman (2000). Alternative analytical methods, or required detection limits, will be allowed if evaluation by Groundwater Monitoring Project staff considers them compatible with regulatory standards, and with project missions and goals. Such changes will be documented in revisions of the Quality Control (QC) plan or changes to the laboratory contracts. 
Table 3.3. Analytical Performance Requirements

\begin{tabular}{|c|c|c|c|c|c|c|}
\hline $\begin{array}{l}\text { Type of } \\
\text { COC }\end{array}$ & $\mathrm{COCs}$ & Analytical Method & $\begin{array}{l}\text { Action Level } \\
\text { (MCL) }\end{array}$ & $\begin{array}{c}\text { Contract } \\
\text { Required } \\
\text { Detect Limit }\end{array}$ & $\begin{array}{l}\text { Precision } \\
(\% \text { RSD })^{(a)}\end{array}$ & $\begin{array}{l}\text { Recommended } \\
\text { Recovery } \\
(\%)\end{array}$ \\
\hline \multirow[t]{3}{*}{$\begin{array}{l}\text { Radio- } \\
\text { nuclide }\end{array}$} & Sr-90 & $\begin{array}{l}\text { Gas Proportional counting; Method } \\
905.0 \text { (Krieger and Whittaker 1980) }\end{array}$ & $8 \mathrm{pCi} / \mathrm{L}$ & $2 \mathrm{pCi} / \mathrm{L}$ & $\pm 20 \%$ & $70-130 \%$ \\
\hline & Tritium & $\begin{array}{l}\text { Liquid scintillation; Method } 906.0 \\
\text { (Krieger and Whittaker 1980) }\end{array}$ & $20,000 \mathrm{pCi} / \mathrm{L}$ & $400 \mathrm{pCi} / \mathrm{L}$ & $\pm 20 \%$ & $70-130 \%$ \\
\hline & Uranium & $\begin{array}{l}\text { Fluorometry or laser kinetic } \\
\text { phosphorimetry }\end{array}$ & $30 \mu \mathrm{g} / \mathrm{L}$ & $0.1 \mu \mathrm{g} / \mathrm{L}$ & $\pm 20 \%$ & $70-130 \%$ \\
\hline \multirow[t]{5}{*}{ Metal } & Chromium & $\begin{array}{l}\text { Inductively coupled plasma } \\
\text { emission spectrometry; Method } \\
6010 \text { (SW-846) }\end{array}$ & $100 \mu \mathrm{g} / \mathrm{L}$ & $10 \mu \mathrm{g} / \mathrm{L}$ & $\pm 20 \%$ & $80-120 \%$ \\
\hline & $\begin{array}{l}\text { Hexavalent } \\
\text { Chromium }^{(b)}\end{array}$ & $\begin{array}{l}\text { BHI-EE-002 Procedure } 1.17 \text { or } \\
\text { equivalent }\end{array}$ & $100 \mu \mathrm{g} / \mathrm{L}$ & N/A & N/A & N/A \\
\hline & Aluminum $^{(\mathrm{c})}$ & $\begin{array}{l}\text { Inductively coupled plasma } \\
\text { emission spectrometry; Method } \\
6010 \text { (SW-846) }\end{array}$ & $50 \mu \mathrm{g} / \mathrm{L}$ & $200 \mu \mathrm{g} / \mathrm{L}$ & $\pm 20 \%$ & $80-120 \%$ \\
\hline & Iron & $\begin{array}{l}\text { Inductively coupled plasma } \\
\text { emission spectrometry; Method } \\
6010 \text { (SW-846) }\end{array}$ & $300 \mu \mathrm{g} / \mathrm{L}$ & $100 \mu \mathrm{g} / \mathrm{L}$ & $\pm 20 \%$ & $80-120 \%$ \\
\hline & Manganese & $\begin{array}{l}\text { Inductively coupled plasma } \\
\text { emission spectrometry; Method } \\
6010 \text { (SW-846) }\end{array}$ & $50 \mu \mathrm{g} / \mathrm{L}$ & $15 \mu \mathrm{g} / \mathrm{L}$ & $\pm 20 \%$ & $80-120 \%$ \\
\hline Anion & $\begin{array}{l}\text { Nitrate } \\
\left(\text { as } \mathrm{NO}_{3}^{-}\right)\end{array}$ & $\begin{array}{l}\text { EPA Method } 300.0 \text { (Krieger and } \\
\text { Whittaker 1980) }\end{array}$ & $45,000 \mu \mathrm{g} / \mathrm{L}$ & $250 \mu \mathrm{g} / \mathrm{L}$ & $\pm 25 \%$ & $75-125 \%$ \\
\hline $\begin{array}{l}\text { Volatile } \\
\text { Organic } \\
\text { Compound }\end{array}$ & Trichloroethene ${ }^{(\mathrm{c})}$ & $\begin{array}{l}\text { EPA Method } 8010 / 8020 / 8260 \\
(\mathrm{SW}-846)\end{array}$ & $5 \mu \mathrm{g} / \mathrm{L}$ & $5 \mu \mathrm{g} / \mathrm{L}$ & $\pm 25 \%$ & $75-125 \%$ \\
\hline \multicolumn{7}{|c|}{$\begin{array}{l}\text { (b) An ARAR for hexavalent chromium in groundwater near the shoreline of } 22 \mu \mathrm{g} / \mathrm{L} \text { has been established based on fish toxicity } \\
\text { with an allowance for initial mixing with river water. The method detection limit in this case is } 2 \mu \mathrm{g} / \mathrm{L} \text {. } \\
\text { (c) The method detection limits for aluminum and trichloroethene are } 16.5 \text { and } 0.29 \mu \mathrm{g} / \mathrm{L} \text {, respectively. }\end{array}$} \\
\hline
\end{tabular}




\subsection{Step 4: Define the Boundaries of the Study}

The primary objective of DQO step 4 is to identify the population of interest, define the spatial and temporal boundaries that apply to each decision statement, define the scale of decision making, and identify any practical constraints that must be taken into consideration in the sampling design. Implementing this step is intended to assure that the sampling design will result in the collection of data that accurately reflect the true condition of the site under investigation.

\subsection{Population of Interest}

Prior to defining the spatial and temporal boundaries of the site, it is necessary to clearly define the populations of interest that apply to each decision statement (Table 4.1). Table 4.1 clearly defines the attributes that make up each population of interest.

Table 4.1. Characteristics that Define the Population of Interest

\begin{tabular}{||l|l|l||}
\hline \multicolumn{1}{|c|}{ Population of Interest (Issues) } & \multicolumn{1}{|c||}{$\begin{array}{l}\text { Unit Measurement } \\
\text { Size }\end{array}$} & \multicolumn{1}{|c||}{$\begin{array}{l}\text { Total Number of Potential } \\
\text { Measurement Units Within } \\
\text { the Population }\end{array}$} \\
\hline \hline $\begin{array}{l}\text { DS\#1. Concentrations of selected COCs } \\
\text { key groundwater wells with depth. }\end{array}$ & \multicolumn{1}{|c||}{ Many } \\
\hline DS\#2. Concentrations of COCs ${ }^{(\text {a) }}$ in groundwater & $\sim 1$ liter & Many \\
\hline $\begin{array}{l}\text { DS\#3. Placement of monitoring wells (and/or } \\
\text { hyporheic sampling points) }\end{array}$ & $\begin{array}{l}\text { Number of wells (and/or } \\
\text { hyporheic sampling } \\
\text { points) }\end{array}$ & Varies ${ }^{(\mathrm{b})}$ (See Figure 4.3) \\
\hline DS\#4. Sample frequency & Samples/year & Many \\
\hline $\begin{array}{l}\text { (a) COCs for the 100-BC-5 and 100-FR-3 operable units are defined in Table 3.2. } \\
\text { (b) Subject to budget constraint allocated for drilling new wells, if any, as indicated by priority. }\end{array}$ \\
\hline
\end{tabular}

\subsection{Geographic Boundaries}

Figure 4.1 and Table 4.2 identify the horizontal geographic boundaries that apply to each decision statement associated with groundwater monitoring in the 100-BC-5 and 100-FR-3 operable units. Limiting geographic boundaries of the study area ensures that the investigation does not expand beyond original scope of the task. The "Operable Unit Boundaries" shown in Figure 4.2 represent the initial geographic boundary conditions applied to each area during the initial stages of the clean-up process. The "Groundwater Interest Areas" represent the revised boundary areas, which include the original clean-up boundaries as well as plume boundaries identified as a consequence of subsequent sampling efforts. 


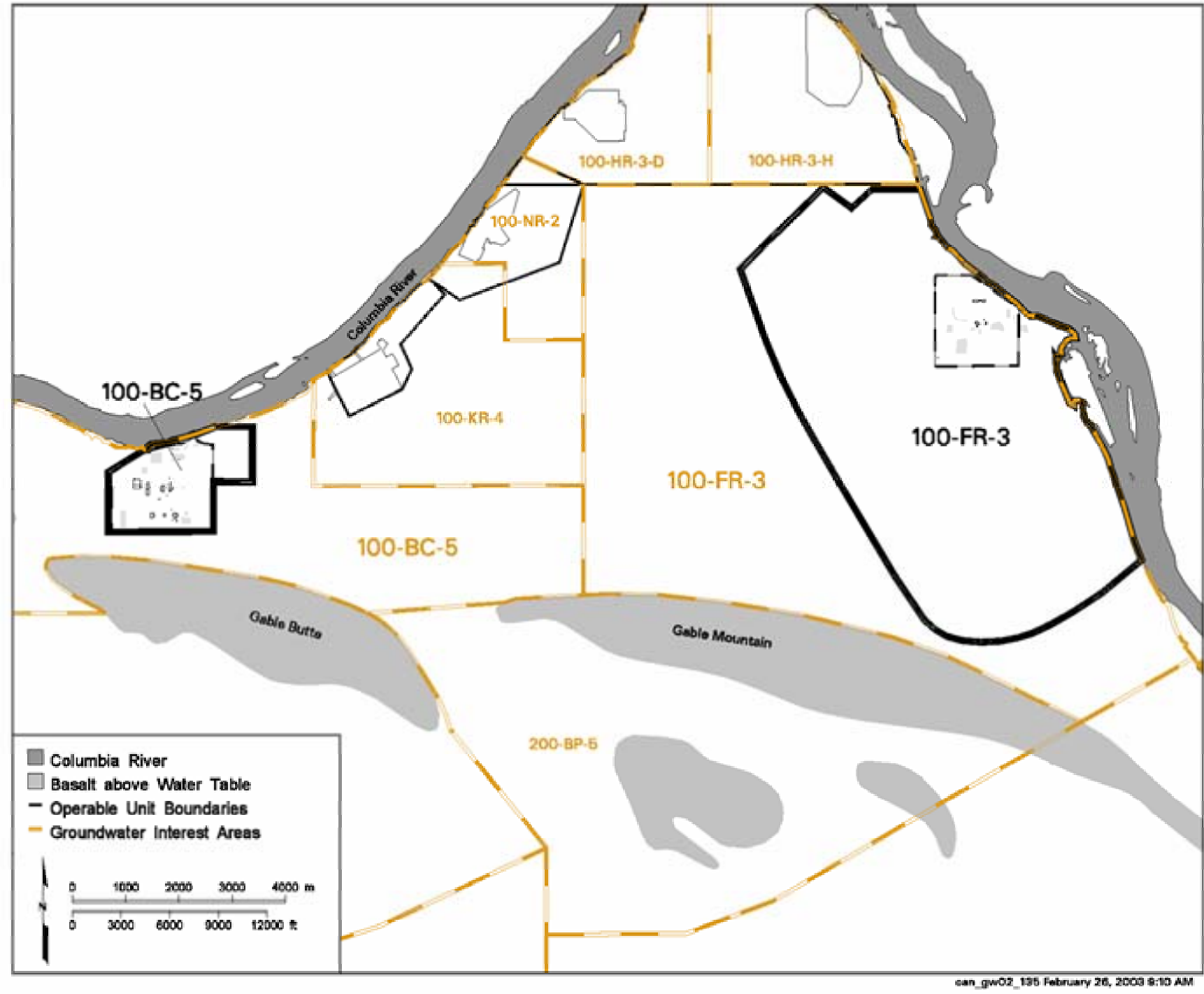

Figure 4.1. Geographical Boundaries for the 100-B/C and 100-F Areas 
Table 4.2. Geographic Boundaries of the Investigation

\begin{tabular}{||l|c|l||}
\hline \hline Operable Unit & DS \# & \multicolumn{1}{c|}{ Geographic Boundaries of the Investigation } \\
\hline \hline 100-BC-5 & $1-4$ & $\begin{array}{l}\text { The northern boundary is the shoreline along the Columbia River. The western, } \\
\text { southern, and eastern boundaries are extended beyond the 100-BC-5 operable unit, } \\
\text { including portions of the 600 Area as identified in Figure 4.1 }\end{array}$ \\
\hline 100-FR-3 & $1-4$ & $\begin{array}{l}\text { The northeastern boundary is the shoreline along the Columbia River. The } \\
\text { western, southern, and eastern boundaries are extended beyond the 100-FR-3 } \\
\text { operable unit including portions of the 600 Area as identified in Figure 4.1 }\end{array}$ \\
\hline
\end{tabular}

\subsubsection{Zones with Homogeneous Characteristics}

Table 4.3 defines the zones within the site under investigation that have relatively homogeneous physical characteristics. Dividing the site into separate zones having relatively homogeneous characteristics reduces the overall complexity of the problem by breaking the site into more manageable pieces. For example, more than one hydrostratigraphic unit occurs with depth beneath each operable unit. While groundwater characteristics may be relatively homogeneous within each hydrostratigraphic unit, there may be distinct differences between hydrostratigraphic units. Thus, site-specific hydrostratigraphy is used to define the vertical boundaries of the investigation (Table 4.3).

Table 4.3. Vertical Boundaries of the Investigation

\begin{tabular}{|c|c|c|}
\hline DS \# & Issue or Population of Interest & Zone \\
\hline \multicolumn{3}{|c|}{ 100-BC-5 and 100-FR-3 Operable Units } \\
\hline \multirow{3}{*}{$\begin{array}{l}1,2 \text {, and } \\
4\end{array}$} & \multirow{3}{*}{$\begin{array}{l}\text { Strontium-90, tritium, chromium, hexavalent chromium, } \\
\text { aluminum, and iron concentrations in groundwater beneath the } \\
\text { 100-BC-5 boundary (see Figure } 4.1 \text { ) } \\
\text { Strontium-90, tritium, chromium, hexavalent chromium, } \\
\text { trichloroethene, nitrate, uranium, and manganese concentrations } \\
\text { in groundwater beneath the } 100-\text { FR-3 boundary (see Figure } 4.1 \text { ). }\end{array}$} & Unconfined aquifer \\
\hline & & Confined Ringold \\
\hline & & Confined basalt aquifer \\
\hline \multirow[t]{3}{*}{3} & \multirow[t]{3}{*}{ Well placement } & Unconfined aquifer \\
\hline & & Confined Ringold \\
\hline & & Confined basalt aquifer \\
\hline
\end{tabular}

\subsubsection{Temporal Boundaries}

Table 4.4 identifies temporal boundaries that may apply to each decision statement. The temporal boundary refers to:

- $\quad$ timeframe over which the monitoring network defined in DQO Step 7 will apply (i.e., 2003 until there is a ROD, which is anticipated to be 2016)

- $\quad$ optimal sampling intervals between 2003 and 2016 (DOE 2001). 
The monitoring well network and sampling frequency should be re-evaluated periodically because sampling needs will change as the extent of the contaminant plume changes.

Table 4.4. Temporal Boundaries of the Investigation

\begin{tabular}{||l|l|l||}
\hline DS \# & \multicolumn{1}{|c||}{ Timeframe $^{(\text {a) }}$} & \multicolumn{1}{|c||}{ When to Collect Data } \\
\hline \hline 1-4 & $\begin{array}{l}\text { Groundwater samples collected from selected } \\
\text { wells and hyporheic sampling points as necessary } \\
\text { to verify mixing effects. } \\
\text { Samples collected at a minimum frequency of at } \\
\text { least two times before the next 5-year review } \\
\text { (FY04 and FY05). Collection of more or fewer } \\
\text { samples, however, will be based on the specific } \\
\text { needs of individual well locations (e.g., } \\
\text { variability of concentration, proximity of well } \\
\text { locations to source units and the Columbia River. }\end{array}$ & $\begin{array}{l}\text { In areas that are close to the vadose zone sources, } \\
\text { rising water levels may mobilize vadose zone } \\
\text { contamination, resulting in subsequent increases in } \\
\text { contaminant concentrations in groundwater. In these } \\
\text { cases, samples should be collected when river stage is } \\
\text { high (spring-early summer). } \\
\text { Mixing with ambient river water is expected in the } \\
\text { stream bank storage zone near the shoreline, resulting } \\
\text { in dilution of the contaminant plume prior to entering } \\
\text { the free-flowing portion of the river. Springs and } \\
\text { hyporheic sampling point samples must be collected } \\
\text { annually during the low water period. }\end{array}$ \\
\hline
\end{tabular}

\subsection{Scale of Decision Making}

In Table 4.5, the scale of decision-making has been defined for each decision statement by considering the population of interest, the geographic and temporal boundaries of the area under investigation, and risk factors, as appropriate. For purposes of this DQO, the risk factors considered were 1) occasional exposure of an individual to water at the stream bank, 2) ingestion of edible tissue (e.g. freshwater mussels) occasionally used by humans, and 3) exposure of potential salmon spawning beds near the shoreline. Human exposure to well water during the time frame of interest (until 2016) was not considered likely, because institutional controls are in place for this time period.

\subsection{Potential Constraints}

Potential constraints that could interfere with the implementation of the groundwater-monitoring program outlined in Step 7 are as follows:

- $\quad$ budgetary resource fluctuations

- well maintenance or pump problems could impede collection of some samples

- $\quad$ because of surface remediation activities, certain wells may be eliminated from the existing network

- $\quad$ discovery of previously undetected contaminant plumes 
- unanticipated remobilization of residual contamination following source remediation activities

- discovery of unanticipated impacts as a result of the 100-B/C Pilot Risk Assessment (Doctor et al. 2003).

Table 4.5. Scale of Decision Making

\begin{tabular}{|c|c|c|c|c|c|}
\hline \multirow[b]{2}{*}{ DS \# } & \multirow{2}{*}{$\begin{array}{l}\text { Issue or } \\
\text { Population of } \\
\text { Interest }\end{array}$} & \multirow[b]{2}{*}{$\begin{array}{l}\text { Geographic } \\
\text { Boundary }\end{array}$} & \multicolumn{2}{|c|}{ Temporal Boundary } & \multirow[b]{2}{*}{$\begin{array}{l}\text { Scale of } \\
\text { Decision }\end{array}$} \\
\hline & & & Timeframe $^{(a)}$ & $\begin{array}{c}\text { When to Collect } \\
\text { Data }\end{array}$ & \\
\hline \multicolumn{6}{|c|}{ 100-BC-5 and 100-FR-3 Operable Units } \\
\hline 1 and 4 & $\begin{array}{l}\text { Concentrations } \\
\text { of selected } \\
\text { constituents }^{(b)} \\
\text { in selected key } \\
\text { groundwater } \\
\text { wells with } \\
\text { depth. }\end{array}$ & $\begin{array}{l}\text { Parameters of } \\
100-B C-5 \text { and } \\
100-F R-3 \\
\text { compliance } \\
\text { boundary as } \\
\text { defined in } \\
\text { Figure } 4.1\end{array}$ & $\begin{array}{l}\text { Between now and } 2016 . \\
\text { Samples collected at minimum } \\
\text { at a frequency sufficient to } \\
\text { meet the needs of the } 5 \text {-year } \\
\text { review. Collection of more or } \\
\text { fewer samples will be based } \\
\text { on the specific needs of } \\
\text { individual well locations (e.g., } \\
\text { variability of concentration, } \\
\text { proximity of well locations to } \\
\text { source units and the Columbia } \\
\text { River). }\end{array}$ & $\begin{array}{l}\text { At least once } \\
\text { during high water } \\
\text { and once during } \\
\text { low water time of } \\
\text { year in selected } \\
\text { wells, early in the } \\
\text { timeframe of } \\
\text { interest. }\end{array}$ & $\begin{array}{l}\text { Concentration } \\
\text { of selected } \\
\text { constituents } \\
\text { with depth } \\
\text { within } \\
\text { contaminant } \\
\text { plume area }\end{array}$ \\
\hline 2 and 4 & $\begin{array}{l}\text { Concentrations } \\
\text { of } \\
\text { constituents }^{(b)} \\
\text { in groundwater }\end{array}$ & Same as above & Same as above & $\begin{array}{l}\text { Annually along } \\
\text { shoreline; at least } \\
\text { biennially within } \\
\text { interior of study } \\
\text { boundary }\end{array}$ & $\begin{array}{l}\text { Along entire } \\
\text { shoreline of } \\
\text { each unit and } \\
\text { over plume } \\
\text { dimensions (or } \\
\text { specific } \\
\text { sources) } \\
\text { within each } \\
\text { unit }\end{array}$ \\
\hline 3 & $\begin{array}{l}\text { Placement of } \\
\text { monitoring } \\
\text { wells (and/or } \\
\text { hyporheic } \\
\text { sampling } \\
\text { points) }\end{array}$ & Same as above & Same as above & $\mathrm{N} / \mathrm{A}$ & $\begin{array}{l}\text { Along entire } \\
\text { shoreline of } \\
\text { each unit and } \\
\text { over plume } \\
\text { dimensions (or } \\
\text { specific } \\
\text { sources) } \\
\text { within each } \\
\text { unit }\end{array}$ \\
\hline \multicolumn{6}{|c|}{$\begin{array}{l}\text { (a) Until there is a ROD anticipated to be } 2016 \text {. } \\
\text { (b) Lists of constituents of potential concern for the } 100-\mathrm{BC}-5 \text { and } 100 \text {-FR-3 operable units are defined in } \\
\text { Table } 3.2 \text {. }\end{array}$} \\
\hline
\end{tabular}




\subsection{Step 5: Develop Decision Rules}

The purpose of this step is to develop a decision rule (DR) for each decision statement in the form of an IF-THEN statement that incorporates the parameter of interest, the scale of decision-making, the action level, and the alternative actions that would result from resolution of the decision.

The primary information needed for this step includes parameters that characterize the population of interest and action levels for decisions along with related information as summarized Table 5.1 and discussed in the paragraphs below.

Table 5.1. Inputs Needed to Develop Decision Rules

\begin{tabular}{|c|c|c|c|c|c|}
\hline DS \# & $\begin{array}{c}\text { Issue or Population of } \\
\text { Interest }\end{array}$ & Parameter of Interest & $\begin{array}{c}\text { Scale of Decision } \\
\text { Making }\end{array}$ & $\begin{array}{l}\text { Action } \\
\text { Level }\end{array}$ & Alternative Actions \\
\hline \multicolumn{6}{|c|}{ 100-BC-5 and 100-FR-3 Operable Units } \\
\hline 1 & $\begin{array}{l}\text { Complete listing of } \\
\text { constituents of potential } \\
\text { concern is presented in } \\
\text { Table } 3.2 \text {. However, for } \\
\text { this decision statement, } \\
\text { selected key } \\
\text { constituents as } \\
\text { determined by the DQO } \\
\text { process are adequate. }\end{array}$ & $\begin{array}{l}\text { Concentration profile } \\
\text { with depth and rate of } \\
\text { decline. }\end{array}$ & $\begin{array}{l}\text { Concentration of } \\
\text { selected } \\
\text { constituents with } \\
\text { depth within } \\
\text { contaminant } \\
\text { plume area }\end{array}$ & $\begin{array}{l}\text { Defined in } \\
\text { Table } 3.3\end{array}$ & $\begin{array}{l}\text { 1) No action. } \\
\text { 2) Select key wells and } \\
\text { determine vertical } \\
\text { variability. }\end{array}$ \\
\hline 2 & $\begin{array}{l}\text { List of constituents per } \\
\text { Sweeney (2002a and } \\
2002 b)\end{array}$ & $\begin{array}{l}\text { Number of detected } \\
\text { analyses over total } \\
\text { analyses; maximum } \\
\text { concentrations in } \\
\text { relation to Action } \\
\text { Level; variability of } \\
\text { detected analyses; etc. }\end{array}$ & $\begin{array}{l}\text { Along entire } \\
\text { shoreline of each } \\
\text { unit and over } \\
\text { plume } \\
\text { dimensions (or } \\
\text { specific sources) } \\
\text { within each unit }\end{array}$ & $\begin{array}{l}\text { Defined in } \\
\text { Table } 3.3\end{array}$ & $\begin{array}{l}\text { 1) No action. } \\
\text { 2) Determine if a reduced } \\
\text { list of key indicators or } \\
\text { surrogate can be used. }\end{array}$ \\
\hline 3 & $\begin{array}{l}\text { Placement of } \\
\text { monitoring wells } \\
\text { (and/or hyporheic } \\
\text { sampling points) }\end{array}$ & $\begin{array}{l}\text { Well spacing or } \\
\text { coverage }\end{array}$ & $\begin{array}{l}\text { Along entire } \\
\text { shoreline of each } \\
\text { unit and over } \\
\text { plume } \\
\text { dimensions (or } \\
\text { specific sources) } \\
\text { within each unit }\end{array}$ & $\mathrm{N} / \mathrm{A}$ & $\begin{array}{l}\text { 1) No action. } \\
\text { 2) Drill and install new } \\
\text { monitoring wells. } \\
\text { 3) Install a larger array of } \\
\text { hyporheic sampling points. } \\
\text { 4) Use a few indicator } \\
\text { wells in key locations } \\
\text { (combined with } 3 \text { ). } \\
\text { 5) Monitor the Ringold or } \\
\text { upper basalt confined } \\
\text { aquifers, if needed. }\end{array}$ \\
\hline
\end{tabular}


Table 5.1. (contd)

\begin{tabular}{|c|c|c|c|c|c|}
\hline DS \# & $\begin{array}{l}\text { Issue or Population of } \\
\text { Interest }\end{array}$ & Parameter of Interest & $\begin{array}{c}\text { Scale of Decision } \\
\text { Making }\end{array}$ & $\begin{array}{c}\text { Action } \\
\text { Level }\end{array}$ & Alternative Actions \\
\hline 4 & Sampling frequency & $\begin{array}{l}\text { Number of detected } \\
\text { analyses over total } \\
\text { analyses; maximum } \\
\text { concentrations in } \\
\text { relation to Action } \\
\text { Level; variability of } \\
\text { detected analyses; } \\
\text { trend plots of } \\
\text { constituents } \\
\text { concentration versus } \\
\text { time, contour maps, } \\
\text { monitoring data } \\
\text { obtained from seeps } \\
\text { and tubes, and } \\
\text { contaminant(s) } \\
\text { migration rate(s). }\end{array}$ & $\begin{array}{l}\text { Along entire } \\
\text { shoreline of each } \\
\text { unit and over } \\
\text { plume } \\
\text { dimensions (or } \\
\text { specific sources) } \\
\text { within each unit }\end{array}$ & N/A & $\begin{array}{l}\text { 1) No action. } \\
\text { 2) Determine adequate } \\
\text { sample frequency of seeps } \\
\text { and tubes. } \\
\text { 3) Determine the location } \\
\text { of increased sampling } \\
\text { frequency downgradient of } \\
\text { representative waste sites. }\end{array}$ \\
\hline
\end{tabular}

\subsection{Action Levels}

The assumed action levels for COCs are the corresponding MCL or drinking water standard (DWS) for each COC. As previously noted, the use of the MCL or DWS is highly conservative as applied to groundwater that will undergo dilution prior to entering the river. An ARAR of $22 \mu \mathrm{g} / \mathrm{L}$ for hexavalent chromium has been established based on fish toxicity with an allowance for mixing/dilution of groundwater with river water (see discussion in Step 3, Basis for Setting the Action Level). ARARs for other COCs will be used if or when they are established from anticipated risk assessments for the shoreline/ riparian zone. Exceedance of action levels would be confirmed by resampling as currently done in the RCRA groundwater program.

A special case or exception to the above is where there is an upgradient source for a COC. In these cases, the action or response to an exceedance would not trigger activities associated with the $100-\mathrm{B} / \mathrm{C}$ or $100-\mathrm{F}$ units. The response in this case is to notify DOE who would then notify the appropriate regulator(s).

\subsection{Decision Rules}

Table 5.2 presents decision rules that correspond to each of the decision statements identified in Table 5.1. 
Table 5.2. Decision Rules

\begin{tabular}{||l|l||}
\hline \multicolumn{1}{|c||}{ DS \# } & \multicolumn{1}{c||}{ Decision Rules } \\
\hline \hline $\begin{array}{l}\text { 1. Contaminant } \\
\text { variation with depth }\end{array}$ & $\begin{array}{l}\text { If a contaminant concentration varies with depth/season in those wells subject to } \\
\text { fluctuations in water level due to river stage, then consider a sampling strategy or method } \\
\text { that eliminates or reduces the influence of vertical movement of the contaminant zone on } \\
\text { observed concentrations. }\end{array}$ \\
\hline $\begin{array}{l}\text { 2. Concentration and } \\
\text { areal distribution of } \\
\text { contaminants }\end{array}$ & $\begin{array}{l}\text { 1) If a contaminant is essentially not detected in a well, using most recent data, then } \\
\text { consider eliminating it from the monitoring list. } \\
\text { 2) If a contaminant is detected, using most recent data, but the maximum detected } \\
\text { concentration is less than Hanford Site groundwater background (DOE/RL 1997), then } \\
\text { consider eliminating it from the monitoring list. } \\
\text { 3) If a contaminant concentration exceeds its MCL, DWS or an ARAR (e.g., 22 } \mu \text { g/L for } \\
\text { hexavalent chromium) in any new well or hyporheic sampling point installed in the future } \\
\text { (including variable depth sampling results), then further assessment and responses are } \\
\text { required. (Exceedances have already been identified in existing monitoring wells; see } \\
\text { Appendix). }\end{array}$ \\
\hline $\begin{array}{l}\text { 3. Adequacy of well } \\
\text { spacing }\end{array}$ & $\begin{array}{l}\text { N/A (Addition of new wells or use a combination of existing wells and new hyporheic } \\
\text { sampling points to reduce gaps in spatial coverage will be based on expert judgment). }\end{array}$ \\
\hline 4. Sample frequency & $\begin{array}{l}\text { 1) If hyporheic sampling points are chosen for enhancing the network or in lieu of new } \\
\text { monitoring wells, sampling frequency will occur, at a minimum, annually (e.g., during the } \\
\text { low water period). } \\
\text { 2) If seasonal variation is noted in existing monitoring wells and the maximum concen- } \\
\text { tration is greater than the MCL, using the most recent data, then sampling twice/year is } \\
\text { indicated. } \\
\text { 3) If variability of detected analyses is low (e.g., coefficient of variation is less than 50\%) } \\
\text { and maximum concentration is less than MCL, or a decreasing trend is noted, then reduce } \\
\text { sample frequency to biennially. } \\
\text { 4) If contaminant(s) migration rate(s) are slow, then sample less frequently. } \\
\text { 5) If wells are located downgradient of representative waste sites, consider increasing } \\
\text { sampling frequency. }\end{array}$ \\
\hline \hline
\end{tabular}




\subsection{Step 6: Specify Tolerable Limits on Decision Errors}

This step is intended to specify performance criteria expressed as probability limits on potential errors in decision-making. The probability limits specify the level of confidence the site manager desires in conclusions drawn from the site data.

The primary decision for this DQO involves the question of adequacy of spatial coverage of the monitoring networks and refinement of constituent list. Traditional statistics cannot be applied to spatial aspects of designing a groundwater-monitoring network due to the nature of the medium (Thornton and Lindberg 2002). Furthermore, because a new groundwater monitoring well in the 100 Areas costs are higher than hyporheic sampling points to drill and install prior to sampling, traditional statistical sampling designs (e.g., using a sampling grid with randomized design or systematic design) are not feasible for groundwater investigations. Thus, tables defining the null hypothesis, alpha and beta error, and width of the gray region have been excluded from this DQO process. It is concluded that non-statistical (expert judgment) methods will be used primarily as the basis for sampling design. 


\subsection{Step 7: Optimize the Design}

The purpose of the $7^{\text {th }}$ and last step is to identify a resource-effective field investigation sampling design that generates data expected to meet the decision performance criteria specified in previous steps. Additional iterations of this step may be needed to arrive at the optimum design. The output of this step is the sampling design that will guide preparation of the quality assurance project plan (QAPP) and the field-sampling plan (FSP). The FSP and QAPP are combined to create the Sampling and Analysis Plan (SAP). The SAP also provides a system for planning and approving field activities and is the basis for estimating the cost of data collection activities.

Since the spatial coverage of sampling points is of primary importance for this DQO, decision statement 3 (adequacy of well spacing) is considered first. The other decision statements are related to either sampling from a monitoring well or the kinds and number of measurements needed for each well. Thus, the number and types of monitoring points potentially needed must be established before overall optimization of available resources, number of constituents, and sampling frequency can be completed.

\subsection{Monitoring Network (DS \#3)}

Because contaminant exceedances in groundwater monitoring wells and a limited number of hyporheic sampling points have already been documented at both operable units (OUs), and approximate plume dimensions estimated, the primary emphasis should now be on refining the estimated size (width) of the plumes entering the river and on the magnitude and spatial variability of COC concentrations at the shoreline boundary of the OUs. This can most efficiently be achieved by increasing the number of hyporheic sampling point sampling points along the shoreline boundaries of both operable units.

\subsubsection{Hyporheic Sampling Points}

Approximately 100 hyporheic sampling points could be installed for the price of a single standard monitoring well. Thus, this type of sampling point is a very cost efficient approach to meeting the above technical objective of providing better definition of the size and concentrations of the known contaminant plumes entering the river.

Enhancing the spatial coverage at the point of entry to the river using hyporheic sampling points would serve a multiple of program objectives, including:

- provide better documentation of concentrations (and flux) of contaminants actually entering the river (i.e., via the riverbed)

- $\quad$ reduce influence of water table fluctuations by sampling during period of sustained, low river stage to provide for tracking the post-remediation rate of decline of groundwater contamination 
- improve the database for "calibrating" contaminant transport models for use in risk assessments of contaminants released to the river.

The rate of decline of a contaminant is determined from trend plots by either linear regression or other suitable methods using contaminant concentration data from a single monitoring point or an average of data from a suitable grouping of points. As previously noted, this type of information is needed to assess the effectiveness of natural attenuation or any previously conducted cleanup action. A negative slope indicates improvement while a positive slope indicates potential problem areas that either were not previously discovered or known soil column sources of groundwater contamination that have not yet been remediated.

Groundwater flow rate, concentration data from the array of monitoring points and cross sectional area of the aquifer could be used to estimate the mass input rate, $\mathrm{R}$, of contaminant to the river. This performance parameter and its application may be beyond the scope of this DQO and associated sampling and analysis plan. However, it is important to understand how the data generated from this DQO will be used in other programs. Accordingly, the basic components of the mass input rate estimate (for a particular contaminant) are discussed below. For example, during the $j^{\text {th }}$ year of the CERCLA 5-year review cycle $(j=, 1,2,3,4,5)$ the basic mass input rate equation can be expressed as follows.

$$
R_{j}=\sum_{i=1 \ldots}^{n} A_{i j} * \bar{v} * C_{i j}
$$

Where $R_{j}=$ mass per unit time of contaminant C (e.g., $\mathrm{kg} / \mathrm{yr}$ or $\left.\mathrm{Bq} / \mathrm{yr}\right)$ in the $\mathrm{j}^{\text {th }}$ year

$A_{i j}=$ cross sectional area $\left(\mathrm{m}^{2}\right)$ of aquifer or plume for each shoreline segment, where $\mathrm{i}=1,2$, $\ldots n^{\text {th }}$ shoreline segment for the $j^{\text {th }}$ year

$\bar{v}=$ average groundwater velocity along segment of interest, $\mathrm{m} / \mathrm{yr}$

$C_{i j}=$ average concentration of contaminant within $\mathrm{i}^{\text {th }}$ segment during the $\mathrm{j}^{\text {th }}$ year

The $\mathrm{i}^{\text {th }}$ cross sectional area, during the $\mathrm{j}^{\text {th }}$ year, $\mathrm{A}_{\mathrm{ij}}$ of the aquifer or plume can be estimated from existing monitoring wells near the shoreline. The length of the segment, $\mathrm{n}$, used can either be uniform spacing or based on the results of the hyporheic sampling point data. Groundwater flow rate or velocity (v) has been typically estimated from the water table gradient, effective porosity, and hydraulic conductivity using the Darcy equation. Darcy velocities can also be verified using more direct measurement of groundwater velocity (e.g., single well tracer-pump back tests, flow meter measurements or the arrival time of a contaminant plume). As a minimum, the hydraulic conductivity should be checked in existing monitoring wells near the shoreline. A limited number of near-shore groundwater wells are available for estimating velocity. Therefore, the average of values determined from individual well measurements must be used for all the segments.

The change in mass input rate over time (e.g., slope determined from data points $\mathrm{R}_{1}, \mathrm{R}_{2}, \ldots, \mathrm{R}_{5}$ obtained from above equation) may provide a better indication of post-remediation attenuation rate than 
the rate of decline in a single well since the average concentration of all relevant monitoring points is used to compute the mass input rate from an operable unit. Better plume definition (i.e. well spacing), however, is needed for a reliable estimate.

\subsubsection{Hyporheic Sampling Point Spacing}

A spacing of $60 \mathrm{~m}$ between hyporheic sampling points was used in the 100-D shoreline area to define the width of the chromium plume entering the river. Other network design studies conducted for Hanford hazardous waste units suggest similar spacing. For example, at one Hanford unit a downgradient well spacing at or near the site boundary on the order of $100 \mathrm{~m}$ was needed to achieve a theoretical probability of $>90 \%$ of detecting a contaminant plume arising from anywhere within the site boundary. This result applies over a maximum plume travel distance of about 200 meters or a distance about equivalent to the distance between the shoreline and the nearest major contaminant sources in the 100-BC-5 and 100-FR-3 operable units (i.e., the retention basins and overflow trenches). Sources that are located at greater distances from the shoreline within the OU boundaries would undergo greater lateral dispersion or spreading by the time the hypothetical plume reached the river and would thus require fewer sampling points to achieve a theoretical detection probability of $>90 \%$. Also, the major sources (retention basins and trenches) close to the shoreline have dimensions in the 100 to $200 \mathrm{~m}$ range.

Based on the above considerations, $100 \mathrm{~m}$ for spacing between hyporheic sampling points seems reasonable. After an initial period (e.g., 2 years) the need for this density of sampling points can be revisited and reduced, or if unexpected occurrences are encountered, additional intermediate points (i.e. at $50 \mathrm{~m}$ or mid-way between $100 \mathrm{~m}$ locations) can be added to enhance definition at about the same scale as used for the chromium plume at 100-D.

The length of shoreline at the $100-\mathrm{F}$ and $100-\mathrm{B} / \mathrm{C}$ is about 1,400 and $1,800 \mathrm{~m}$, respectively. This suggests a total of $14(1,400 \mathrm{~m} / 100 \mathrm{~m})$ and $18(1,800 \mathrm{~m} / 100 \mathrm{~m})$ hyporheic sampling point locations, respectively. Assuming the existing hyporheic sampling points can be used, the total number of new locations for 100-F Area is 11 (14 minus 3 existing tubes) and 13 (18 minus 5 existing tubes) at 100-B/C Area. The exact number and locations are deferred to the judgment of the technical personnel involved in preparation of the SAP for each unit.

Considering the modest cost to install a hyporheic sampling point, there is little financial risk in over estimating the number needed as compared to an equivalent number of monitoring wells.

\subsubsection{Additional Monitoring Wells}

A decision concerning adequacy of wells within the study boundary of each OU can be deferred until results of the enhanced shoreline hyporheic sampling point sampling are available. If contaminant exceedances appear in a segment of the shoreline where they were unexpected, additional upgradient wells at likely waste sites may be appropriate. During the interim, the existing well network is judged to be adequate but sampling frequency (discussed later) could be adjusted. 
The number and location of existing monitoring wells (especially those close to the shoreline) provide an opportunity to refine estimates of groundwater velocity through selected aquifer testing projects. As previously noted, this parameter is needed for estimating the mass input rate of contaminants to the river. An assessment of the sufficiency of current hydrologic data will be performed before initiating any new aquifer testing.

As discussed earlier, field determination of groundwater velocity in the screened intervals of wells completed in the uppermost aquifer should be conducted to confirm estimates made from water table gradient and aquifer properties (i.e., Darcy velocity). Such information cannot be obtained from hyporheic sampling points so the existing monitoring wells are critical for improving the estimates of contaminant mass input rates to the river.

\subsection{Seasonal Variability in Monitoring Wells Due to Water Level Changes (DS \#1)}

The depth variability issue (DS \#1) becomes less critical if hyporheic sampling points are selected to upgrade the monitoring network at $100-\mathrm{B} / \mathrm{C}$ and $100-\mathrm{F}$. That is, the objective of understanding seasonal vertical movement in the contaminant plume is to reduce the variability in contaminant concentrations from year to year so that the rate of decline over the period of interest (out to 2016) can be determined. Because hyporheic sampling point samples are typically collected during the low water time of the year, they will always be collected during the similar annual river stage. Also, the sampling should be timed to occur during the period when diurnal fluctuations due to dam operations are reduced for the fall Chinookspawning season. This would provide the maximum stability or reproducibility in water level conditions for sampling from year to year.

Limited vertical sampling should be conducted at least once during high water and once during low water time of the year in one or two key wells, early in the timeframe of interest to determine the magnitude of the possible effect on observed concentrations as an aid in understanding the high degree of variability in contaminant concentrations from the fixed pump depths in the existing monitoring wells. Existing wells close to known sources should be sampled at least annually during high water periods to account for possible mobilization of vadose zone contaminants.

\subsection{Sampling Frequency and Well Trips (DS \#4)}

\subsubsection{Hyporheic Sampling Points}

Hyporheic sampling points, as previously noted, are normally or routinely sampled at a minimum of once per year (i.e., during the low water period). While 24 new monitoring points (11 at the 100-F Area and 13 in the 100-B/C Area) would generate more sampling trips and samples for analysis, the collection cost is considerably lower than for a monitoring well. Also, most of the hyporheic sampling point sampling is done by boat. River access provides the sampling team with the opportunity to sample at any river stage, given an appropriate surface completion. 


\subsubsection{Monitoring Wells}

Because hyporheic sampling points are sampled annually there seems to be little gained by more frequent sampling than this for the monitoring wells. The exception being those wells close to a known or suspected vadose zone source where high water periods are suspected of mobilizing contaminants held in the vadose zone. If seasonal variation in contaminant concentrations is noted in existing monitoring wells, and the maximum concentration is greater than the MCL, then sampling during the time of year when maximum concentrations occur for any contaminant would help to ensure the maximum concentration for the year is captured. This approach could require sampling at more than one time of the year to make sure that all constituents of concern are sampled during their respective seasonal maximum concentrations.

If variability of detected analyses is low (e.g., coefficient of variation is less than $50 \%$ ) and the maximum concentration is less than the MCL, or a decreasing trend is noted and the maximum concentration is less than MCL, then sampling frequency can be reduced. In addition, if wells are located downgradient of representative waste sites, consider increasing sampling frequency.

For constituents such as strontium-90 that migrate very slowly (a few meters per year under natural conditions) a biennial sampling frequency would be adequate. The slow migration rate of strontium-90 is evident by comparing the plume distribution over a few years. For example, at the 100-BC-5 Operable Unit, there is essentially no change in the strontium-90 plume for FY 2001, 2000, and 1998 (see Appendix, Figures A.1 to A.3).

\subsection{Constituent List, Sampling Constraints, and Analytical Alternatives (DS \#2)}

For the proposed new hyporheic sampling point array, alternatives to analyzing all constituents in every sample are to analyze all identified COCs once after the new monitoring points are installed and then routinely analyze only the COCs that exceeded a standard in either the new monitoring facilities or that have previously exceeded a standard in existing monitoring wells (as specified in Table 5.2). Critical parameters, such as hexavalent chromium, could be analyzed in the field-screening mode so that any unexpected exceedance could be documented by resampling within a week of the exceedance event. The short list developed could also be used for the existing monitoring wells.

One problem with the proposed annual (low water) sampling time for hyporheic sampling points is resampling to confirm a suspect value for constituents other than chromium when there is a 45-day laboratory turnaround time. In other words, the window for resampling during the low water period may have passed by the time the lab results are available. One way to address this concern is to consider a short-term sampling to determine the length of time when concentrations are relatively stable. For example, sampling several selected locations on a biweekly basis over a 2-3 month period during or following the seasonal low water period (August to October) would provide such needed information. 
An extension of the evaluation of time dependency of concentration in hyporheic sampling points would be to sample monthly in selected locations for a one-year period. This information may be available from other programs interested in determining the annual variability in hyporheic sampling point concentrations. Or it could be included as a joint effort in the SAP for this DQO effort. Also, by making a conservative estimate of the number of hyporheic sampling points needed (i.e. closer spacing), nearby or adjacent tubes to one with a suspect value can be used to judge the reliability of a suspect result.

Based on existing data (see Appendix, Tables A.1 to A.5) and previously discussed decision rules (Table 5.2), the proposed short list and sampling schedule for each OU are as indicated in Table 7.1 below (except for a newly installed groundwater well). For new wells, sampling on a quarterly basis during the first year is recommended using a broader suite of analytical constituents to provide general knowledge concerning the background or baseline conditions (e.g., sample once for constituents of interest [COCs with site-specific water quality parameters] and sample subsequently based on the results of the detected constituents). The list of constituents to be sampled for each well should be refined in the final SAP using decision rules as described in Table 5.2 (DS\#2 and \#4).

Table 7.1. Recommended List of Constituents and Sample Frequency in Hyporheic Sampling Points and Groundwater Monitoring Wells of the 100-BC-5 and 100-FR-3 Operable Units

\begin{tabular}{||l|c|c|c||}
\hline \multicolumn{1}{|c|}{ Constituent $^{(\mathrm{a}, \mathrm{b}, \mathrm{c})}$} & Sample Frequency ${ }^{(\mathrm{d})}$ & $100-\mathrm{BC}-5$ & $100-\mathrm{FR}-3$ \\
\hline \hline Hexavalent Chromium & $\mathrm{A}$ & $\mathrm{X}$ & $\mathrm{X}$ \\
\hline Strontium-90 & $\mathrm{B}$ & $\mathrm{X}$ & $\mathrm{X}$ \\
\hline Tritium & $\mathrm{A}$ & $\mathrm{X}$ & $\mathrm{X}$ \\
\hline Uranium & $\mathrm{A}$ & $\mathrm{X}$ \\
\hline Nitrate & $\mathrm{A}$ & $\mathrm{X}$ \\
\hline Trichloroethene & A & \\
\hline (a) Iron, aluminum and manganese have appeared as exceedances in previous monitoring well data for the B/C and \\
F areas (Appendix, Tables A.2 to A.5) but were not included in the short list since these are commonly \\
associated with monitoring wells as an artifact of sampling or well conditions. \\
(b) All the constituents listed should be analyzed on unfiltered samples, except when high turbidity is an \\
interference for the colorimetric method used for hexavalent chromium. In the latter case, only sample splits \\
for hexavalent chromium would be filtered. \\
(c) Not all constituents can be sampled during the same season or time of year. For example, strontium-90 maxima \\
in some wells appear to be several months out of phase with highly mobile contaminants (e.g., tritium, nitrate \\
and hexavalent chromium). Thus, two well trips may be required for some wells to achieve annual sampling \\
for all constituents. Existing trend plots can be reviewed to decide the wells for which this special condition \\
applies. \\
(d) Annual sampling for strontium-90 in hyporheic sampling points is recommended so that sufficient data would \\
be available for the 5-year review. After that time, biennial sampling should be adequate. \\
A = Annually. \\
B = Biennially.
\end{tabular}




\subsubsection{Resource Allocation Considerations}

Resources available for implementing the new SAPs based on the outcome of this DQO are unknown at this time. However, as a baseline cost consideration, the existing sampling and analysis costs (per year) could be used. The initial installation cost of the hyporheic sampling points is a one-time cost that is separate from the routine sampling and analysis.

The estimated annual cost for collection and analysis of the short list shown in Table 7.1 for hyporheic sampling points is estimated to be comparable to that of existing groundwater monitoring wells. Assuming these estimates are accurate, a few key existing groundwater monitoring wells could be included and still be within the range of the sampling and analysis costs for the current program.

If staying within the current resources allocated for this site is mandatory, sampling could be conducted in all of the hyporheic sampling points for all constituents (long list) during year 1 and postpone sampling in any of the existing wells until year 2. Following the evaluation of the year 1 hyporheic sampling point results, the number of hyporheic sampling points sampled could be reduced or only one or two key constituents (chromium and nitrate) could be analyzed for every hyporheic sampling point and the full set (Table 7.1) in only selected locations. 


\subsection{References}

Comprehensive Environmental Response, Compensation, and Liability Act of 1980, as amended, Public Law 96-510, 94 Stat. 2767, 42 USC 9601 et seq.

Doctor, P. G., K. A. Gano, R. G. Bauer, J. K. Linville, and T. M. Poston. 2003. 100-B/C Area Ecological Risk Assessment Data Quality Objectives. BHI-01673, Bechtel Hanford, Inc., Richland, Washington.

DOE. 2001. A Report to Congress on Long-Term Stewardship: Volume II-Site Summaries.

DOE/EM-0563, Office of Environmental Management, U.S. Department of Energy, Germantown, Maryland.

DOE-RL. 1994a. Limited Field Investigation Report for the 100-BC-5 Operable Unit. DOE/RL-93-37, Rev. 0. U.S. Department of Energy, Richland Operations Office, Richland, Washington.

DOE-RL. 1994b. Limited Field Investigation Report for the 100-FR-3 Operable Unit. DOE/RL-93-83, U.S. Department of Energy, Richland Operations Office, Richland, Washington.

DOE/RL. 1997. Hanford Site Background: Part 3, Groundwater Background. DOE/RL-96-61, U.S. Department of Energy, Richland Operations Office, Richland, Washington.

EPA. 1994. Guidance for the Data Quality Objectives Process. EPA QA/G-4, U.S. Environmental Protection Agency, Washington, D.C.

EPA. 1996. Interim Record of Decision (ROD) for the 100-HR-3 and 100-KR-4 Operable Units, Hanford Site, Benton County, Washington. Agreement Between U.S. Department of Energy and U.S. Environmental Protection Agency, with Concurrence by Washington State Department of Ecology.

Hartman, M. J. (ed.). 2000. Hanford Site Groundwater Monitoring: Setting, Sources, and Methods. PNNL-13080, Pacific Northwest National Laboratory, Richland, Washington.

Hartman, M. J., L. F. Morasch, and W. D. Webber (eds.). 2002. Hanford Site Groundwater Monitoring for Fiscal Year 2001. PNNL-13788, Pacific Northwest National Laboratory, Richland, Washington.

Krieger, H. L. and E. L. Whittaker. 1980. Prescribed Procedures For Measurement Of Radioactivity In Drinking Water. EPA-600/4-80-032, Environmental Monitoring and Support Laboratory, Office of Research and Development, U.S. Environmental Protection Agency, Cincinnati, Ohio.

PNNL - Pacific Northwest National Laboratory. 2000. The Hanford Groundwater Monitoring Project Quality Assurance Project Plan. QA Plan ETD-012, Rev. 2, Project \# 28023, Pacific Northwest National Laboratory, Richland, Washington. 
Spane, Jr., F. A. and W. D. Webber. 1995. Hydrochemistry and Hydrogeologic Conditions Within the Hanford Upper Basalt Confined Aquifer System. PNL-10817, Pacific Northwest National Laboratory, Richland, Washington.

SW-846. 1986. Test Methods for Evaluating Solid Wastes: Physical/Chemical Methods, 3rd ed. Office of Solid Waste and Emergency Response, U.S. Environmental Protection Agency, Washington, D.C.

Sweeney, M. D. 2000a. Groundwater Sampling and Analysis Plan for the 100-BC-5 Operable Unit. PNNL-13326, Pacific Northwest National Laboratory. Richland, Washington.

Sweeney, M. D. 2000b. Groundwater Sampling and Analysis Plan for the 100-FR-3 Operable Unit. PNNL-13327, Pacific Northwest National Laboratory. Richland, Washington.

Thornton, E. C. and J. W. Lindberg. 2002. Data Quality Objectives Summary Report - Designing a Groundwater Monitoring Network for the 200-BP-5 and 200-PO-1 Operable Units. PNNL-14049, Pacific Northwest National Laboratory, Richland, Washington.

WAC 173-201A-040. Water Quality Standards for Surface Waters of the State of Washington. Washington Administrative Code, Olympia, Washington. 
Appendix

100-BC-5 and 100-FR-3 Data Quality Objectives 


\section{Appendix}

\section{0-BC-5 and 100-FR-3 Data Quality Objectives}

\section{A.1 Background}

The following paragraphs contain background information for the data quality objectives (DQO) efforts. The sources of the background information are DOE (2001) and Peterson et al. (1996).

The $100 \mathrm{~B} / \mathrm{C}$ Area consists of 249 hectares (616 acres), is located immediately adjacent to the Columbia River, and includes the B and C Reactors. The $100 \mathrm{~B} / \mathrm{C}$ Area was the first reactor area to be developed for Hanford. Construction of the B Reactor began in 1942, and the reactor operated from 1944 to 1968. Construction of the C Reactor began in 1951, and the reactor operated from 1952 to 1969.

The $100 \mathrm{~F}$ Area consists of 256 hectares (632 acres) and is located immediately adjacent to the Columbia River near the old town site of White Bluffs. The F Reactor operated from 1945 to 1965 . One unique feature of the $100 \mathrm{~F}$ Area, compared to the other Hanford 100 Areas, is the animal farm research facility. Activities at the animal farm investigated the effect of reactor materials (both transuranics and mixed fission products) on domestic animals.

The B, C, and F Reactors were "single-pass" reactors. Water was pumped from the Columbia River, through the reactor tubes to cool the uranium fuel, and then out of the reactor through large pipelines back into the river. Between the reactors and the river, the cooling water (effluent) was held in large tanks (retention basins) for a short period to allow the short-lived radionuclides, picked up in the reactors to decay and for thermal cooling of the water. Lower concentrations of longer-lived isotopes from these units remained in the cooling water and were discharged directly into the Columbia River where the concentrations declined further due to dilution. There is evidence of Hanford derived radionuclides in the sediment of the Columbia River downstream of Hanford from all Hanford reactors. However, there is no indication of direct impact to human health due to these production-era releases, and much of the contamination passed out of the Columbia River into the Pacific Ocean.

Contaminants were also introduced into the environment in the $100-\mathrm{B} / \mathrm{C}$ and $100-\mathrm{F}$ Areas when some of the basins and pipelines overflowed or leaked, releasing contaminants into the soil. Over the years, large quantities of sludge that settled out in the basins were pumped into disposal trenches near each basin. Each area had sites where solid waste generated during routine reactor operations (contaminated rags, filters, clothing, equipment, disposable supplies, etc.) was buried. In each of the operating areas, some of the contaminants introduced into the soil have migrated to the groundwater, which is relatively close to the surface in the 100 Areas (less than 50 feet in some locations).

Remediation of surface and subsurface soil in the 100 Area is being completed in phases. Remediation in the 100-B/C Area was initiated in late 1995 and will progress until all other areas are completed in 2016. Remediated in the 100-F Area began in fiscal year (FY) 2000 and will be completed 
in 2016. During this period, the U.S. Department of Energy (DOE) is excavating and removing contaminated soil and debris, filling excavated sites, and restoring natural vegetation to the remediated areas. The contaminated soil and other waste are transported and disposed directly in the Environmental Restoration Disposal Facility (ERDF) on the Central Plateau. As the soil is being excavated, samples are taken periodically and analyzed to determine the concentration of contaminants being removed.

Currently, there are no active groundwater remedial activities (e.g., the use of ion exchange to remove strontium-90 or the use of in-situ technology for stabilization chromium contamination) conducted at the 100-B/C-5 and at the 100-FR-3 Operable Unit. Groundwater is not expected to meet current drinking water standards, so the use of groundwater will be restricted through institutional controls.

\section{A.2 Groundwater Flow Directions}

Groundwater flow within the unconfined aquifer is generally north toward the Columbia River in the 100-B/C Area. However, the flow direction periodically shifts to the southeast when river stage is high. River-stage fluctuations strongly affect groundwater flow beneath the 100-F Area. The general direction of unconfined groundwater flow beneath the 100-F Area under normal river-stage conditions is east toward the Columbia River. However, prolonged high-river stage results in groundwater flow toward the southwest near the river and toward the southeast farther inland.

\section{A.3 Monitoring Network and Monitored Constituents}

Groundwater monitoring is conducted in the $100-\mathrm{B} / \mathrm{C}$ Area biannually to annually to describe the nature and extent of contamination. Groundwater monitoring is conducted in the $100 \mathrm{~F}$ Area triennially to annually to describe the nature and extent of contamination, and quarterly to monitor trends in variable constituents/wells (e.g., chromium is sampled quarterly in well 199-F5-46, strontium-90 is sampled quarterly in wells 199-F5-1 and 199-F5-3). Sweeney 2002a and 200b document the specific constituents and sampling frequency at the groundwater wells monitoring the 100-BC-5 and 100-FR-3 Operable Units.

Groundwater near the Columbia River is sampled annually in the late fall via aquifer sampling tubes and riverbank seeps. The sampling tubes are polyethylene tubes that were driven into the aquifer at locations near the low-water shoreline. Seeps are locations where groundwater discharges above the river. The constituents sampled include specific chromium, gross beta, nitrate, conductance, strontium-90, tritium, and for the 100-B/C Area and the 100-F Area.

\section{A.4 Constituents of Potential Concern}

Constituents of concern may be chemical and radiological constituents that pose a risk to human and/or ecological receptors. Numerous regulatory requirements, such as the U.S. Environmental 
Protection Agency (EPA) drinking water standards (40 CFR 141; see maximum contaminant level [MCL]) and ambient water quality criteria (AWQC) for protection of freshwater aquatic organisms, help identify which constituents are of concern.

Limited field investigations (LFI) were completed for the 100-BC-5 Operable Unit (DOE/RL 1994a) and 100-FR-3 Operable Unit (DOE/RL 1994b) that identified constituents of potential concern based on a limited set of data collected in 1992 and 1993. These constituents were used in a qualitative risk assessment, the results of which were used to make decisions regarding an interim remedial measure (IRM). The constituents of concern, conclusions, and recommendations contained in the LFI report and summarized in Peterson et al. (1996) for the 100-B/C-5 and 100-FR-3 are shown in Table A.1.

Table A.1. Constituents of Concern for the 100-B/C-5 and 100-FR-3 Operable Units

\begin{tabular}{|c|c|c|c|}
\hline Operable Unit & Human Health Risk & Ecological Risk & LFI Conclusion and Recommendation \\
\hline $100-\mathrm{B} / \mathrm{C}-5$ & $\begin{array}{l}\text { Carbon-14 } \\
\text { Strontium-90 } \\
\text { Technetium-99 } \\
\text { Tritium }\end{array}$ & $\begin{array}{l}\text { Aluminum } \\
\text { Chromium } \\
\text { Iron } \\
\text { Nickel }\end{array}$ & $\begin{array}{l}\text { An IRM is not required because of the low } \\
\text { risk associated with current site usage. } \\
\text { Remove from IRM pathway. Continue } \\
\text { monitoring until source remediations are } \\
\text { complete, and then reevaluate risk. }\end{array}$ \\
\hline 100-FR-3 & $\begin{array}{l}\text { Arsenic } \\
\text { Chromium } \\
\text { Manganese } \\
\text { Nitrate } \\
\text { Strontium-90 } \\
\text { Tritium }\end{array}$ & $\begin{array}{l}\text { Chromium } \\
\text { Copper } \\
\text { Lead }^{(b)}\end{array}$ & $\begin{array}{l}\text { An IRM is not indicated by human health } \\
\text { or ecological risk. Continue on IRM } \\
\text { pathway; continue RI/FS process. } \\
\text { Trichloroethene, while not a risk driver, } \\
\text { exceeds a potential applicable or relevant } \\
\text { and appropriate requirement (ARAR). }\end{array}$ \\
\hline \multicolumn{4}{|c|}{$\begin{array}{l}\text { (a) Not analyzed after } 1995 \text { (Sweeney 2000a). } \\
\text { (b) Not analyzed after } 1995 \text { (Sweeney 2000b). } \\
\text { ARAR = Applicable or relevant and appropriate requirements. } \\
\text { IRM = Interim remedial action. } \\
\text { LFI = Limited field investigation. } \\
\text { RI/FS = Remedial Investigation/Feasibility Study. }\end{array}$} \\
\hline
\end{tabular}

\section{A.4.1 Summary of Groundwater Contamination Levels}

Table A.2 and Table A.3 list observed concentrations for constituents of potential concern identified during the LRI as well as concentrations for additional waste and water quality indicators for the 100-B/C-5 Operable Unit and the 100-FR-3 Operable Unit, respectively. Table A.4 and Table A.5 provide detailed statistical summary for these constituents and wells in the 100-B/C Area and 100-F Area, respectively. These tables include all results contained in the Hanford Environmental Information System (HEIS) database for sampling conducted from February 1992 to January 2002. Results from several wells in the 600 Area are also included for the purpose to monitor the encroachment of plumes from upgradient area. 
Table A.2. Constituents in 100-B/C Area Wells Where Groundwater Quality Standards Were or Still Are Exceeded

\begin{tabular}{|c|c|c|c|c|c|}
\hline \multirow{2}{*}{$\begin{array}{c}\text { Constituents }^{(\mathrm{a})} \\
\text { (Groundwater } \\
\text { Quality } \\
\text { Standard) }\end{array}$} & \multirow[b]{2}{*}{$\begin{array}{l}\text { Well } \\
\text { Number }\end{array}$} & \multicolumn{2}{|c|}{ Concentration } & \multirow[b]{2}{*}{$\begin{array}{l}\text { Distance } \\
\text { Inland (ft) }\end{array}$} & \multirow[b]{2}{*}{$\begin{array}{l}\text { Remarks/Comments/ } \\
\text { Discussion }\end{array}$} \\
\hline & & $\begin{array}{l}\text { Most Recent } \\
\text { Measurement } \\
\text { (Date) }\end{array}$ & $\begin{array}{l}\text { Maximum } \\
\text { (Date) }\end{array}$ & & \\
\hline $\begin{array}{c}\text { Aluminum }^{(\mathrm{b})} \\
(50 \mu \mathrm{g} / \mathrm{L})\end{array}$ & $\begin{array}{c}199-\mathrm{B} 2-12 \\
199-\mathrm{B} 3-46 \\
199-\mathrm{B} 4-5\end{array}$ & $\begin{array}{l}42.9(1 / 02) \\
38.6(1 / 02) \\
43.2(1 / 02)\end{array}$ & $\begin{array}{c}99.2(3 / 97) \\
85.4(11 / 97) \\
52(4 / 94)\end{array}$ & $\begin{array}{c}350 \\
800 \\
3,650\end{array}$ & $\begin{array}{l}\text { Sporadic occurrences } \\
\text { over time. But, majority } \\
(>70 \%) \text { of data were } \\
\text { below detection limits.. }\end{array}$ \\
\hline $\begin{array}{l}\text { Chromium }^{(b)} \\
(100 \mu \mathrm{g} / \mathrm{L})\end{array}$ & 199-B5-1 & $26(1 / 02)$ & $113(1 / 98)$ & 1,580 & $\begin{array}{l}\text { Constituent of potential } \\
\text { concern to ecological } \\
\text { receptors in river } \\
\text { environment }\end{array}$ \\
\hline $\begin{array}{l}\text { Hexavalent }^{(b)} \\
\text { Chromium } \\
(22 \mu \mathrm{g} / \mathrm{L})\end{array}$ & $\begin{array}{l}199-B 3-47 \\
199-B 5-1\end{array}$ & $\begin{array}{l}30(1 / 02) \\
25(1 / 02)\end{array}$ & $\begin{array}{l}151(7 / 98) \\
140(7 / 98)\end{array}$ & 350 & $\begin{array}{l}\text { Concentration appears } \\
\text { to be decreasing over } \\
\text { time. }\end{array}$ \\
\hline $\begin{array}{c}\text { Iron }^{(\mathrm{b})} \\
(300 \mu \mathrm{g} / \mathrm{L})\end{array}$ & $\begin{array}{c}199-B 3-1 \\
199-B 3-46 \\
199-B 4-5 \\
199-B 4-9 \\
199-B 9-3\end{array}$ & $\begin{array}{l}31.1(1 / 02) \\
\text { ND }(1 / 02) \\
\text { ND }(1 / 02) \\
\text { ND }(2 / 01) \\
\text { ND }(2 / 01)\end{array}$ & $\begin{array}{c}305(4 / 95) \\
470(5 / 96) \\
676(10 / 92) \\
359(11 / 94) \\
644(1 / 93)\end{array}$ & $\begin{array}{c}550 \\
800 \\
3,650 \\
2,900 \\
5,000\end{array}$ & $\begin{array}{l}\text { Iron is a common } \\
\text { constituent of natural } \\
\text { sediments; also } \\
\text { commonly elevated in } \\
\text { carbon-steel well casing. }\end{array}$ \\
\hline $\begin{array}{l}\text { Strontium-90 } \\
(8 \mathrm{pCi} / \mathrm{L})\end{array}$ & $\begin{array}{c}199-\mathrm{B} 3-1 \\
199-\mathrm{B} 3-46 \\
199-\mathrm{B} 3-47 \\
199-\mathrm{B} 4-1 \\
199-\mathrm{B} 4-4 \\
199-\mathrm{B} 4-7 \\
199-\mathrm{B} 4-9 \\
199-\mathrm{B} 5-2 \\
\end{array}$ & $\begin{array}{c}38.2(1 / 02) \\
39.3(1 / 02) \\
24.8(1 / 02) \\
20.7(2 / 00) \\
15.8(1 / 02) \\
3.76(1 / 02) \\
29.4(2 / 01) \\
14(1 / 02) \\
\end{array}$ & $\begin{array}{c}68(3 / 97) \\
150(4 / 93) \\
39.1(1 / 99) \\
23(1 / 93) \\
34.8(1 / 98) \\
8.89(2 / 92) \\
36.3(6 / 97) \\
32.5(4 / 95) \\
\end{array}$ & $\begin{array}{c}550 \\
800 \\
350 \\
2,100 \\
3,160 \\
3,600 \\
2,900 \\
1,685 \\
\end{array}$ & $\begin{array}{l}\text { Common in liquid } \\
\text { effluent disposed to } \\
\text { retention basins and } \\
\text { trenches, and leakage } \\
\text { from pipelines. } \\
\text { Concentrations are } \\
\text { decreasing over time. }\end{array}$ \\
\hline $\begin{array}{c}\text { Tritium } \\
(20,000 \mathrm{pCi} / \mathrm{L})\end{array}$ & $\begin{array}{c}199-\mathrm{B} 3-1 \\
199-\mathrm{B} 3-47 \\
199-\mathrm{B} 5-1 \\
199-\mathrm{B} 5-2 \\
199-\mathrm{B} 8-6 \\
699-65-72 \\
699-72-73\end{array}$ & $\begin{array}{c}2,630(1 / 02) \\
30,600(1 / 02) \\
13,200(1 / 02) \\
4,120(1 / 02) \\
26,700(1 / 02) \\
\operatorname{ND}(3 / 02) \\
14,300(10 / 01)\end{array}$ & $\begin{array}{c}70,100(1 / 98) \\
88,100(1 / 98) \\
41,700(10 / 98) \\
420,000(3 / 97) \\
91,900(1 / 98) \\
28,000(4 / 93) \\
21,300(11 / 00)\end{array}$ & $\begin{array}{c}550 \\
350 \\
1,580 \\
1,685 \\
3,800 \\
9,900 \\
2,280\end{array}$ & $\begin{array}{l}\text { Tritium source may be } \\
\text { residual from fuel } \\
\text { storage basin water, and } \\
\text { tritium production } \\
\text { activities. Decreasing } \\
\text { trend. Also the plume } \\
\text { from } 200 \text { East has } \\
\text { reached this area. }\end{array}$ \\
\hline $\begin{array}{l}\text { (a) Strontium-9( } \\
\text { nickel are co } \\
\text { et al. 1996). } \\
\text { (b) Filtered anal } \\
\text { ND = Not detect }\end{array}$ & cis case & al coicento & or & k; alumi & $\begin{array}{l}\text { Im, chromium, iron, and } \\
\text { eent (Source: Peterson } \\
\text { C Area. }\end{array}$ \\
\hline
\end{tabular}


Table A.3. Constituents in 100-F Area Wells Where Groundwater Quality Standards Were or Still Are Exceeded

\begin{tabular}{|c|c|c|c|c|c|c|}
\hline \multirow{2}{*}{\multicolumn{2}{|c|}{$\begin{array}{l}\text { Constituents }^{(\mathrm{a})} \\
\text { (Groundwater Quality }^{\text {Standard) }}\end{array}$}} & \multirow[b]{2}{*}{ Well Number } & \multicolumn{2}{|c|}{ Concentration } & \multirow[b]{2}{*}{$\begin{array}{l}\text { Distance } \\
\text { Inland (ft) }\end{array}$} & \multirow[b]{2}{*}{$\begin{array}{l}\text { Remarks/Comments/ } \\
\text { Discussion }\end{array}$} \\
\hline & & & $\begin{array}{l}\text { Most Recent } \\
\text { Measurement } \\
\text { (Date) }\end{array}$ & $\begin{array}{l}\text { Maximum } \\
\text { (Date) }\end{array}$ & & \\
\hline & $\begin{array}{c}\text { Chromium }^{(\mathrm{b})} \\
(100 \mu \mathrm{g} / \mathrm{L}) \\
\text { Hexavalent } \\
\text { Chromium }(22 \mu \mathrm{g} / \mathrm{L}) \\
\end{array}$ & $\begin{array}{l}199-F 5-46 \\
199-F 5-46\end{array}$ & $\begin{array}{l}27.8(10 / 01) \\
76(10 / 00)\end{array}$ & $\begin{array}{l}366(5 / 94) \\
208(2 / 00)\end{array}$ & 1,280 & $\begin{array}{l}\text { Isolated occurrence, no obvious } \\
\text { source. Concentration is } \\
\text { decreasing with time }\end{array}$ \\
\hline & $\begin{array}{l}\text { Strontium-90 } \\
\quad(8 \mathrm{pCi} / \mathrm{L})\end{array}$ & $\begin{array}{c}199-F 5-1 \\
199-F 5-3 \\
199-F 5-6 \\
199-F 5-44 \\
199-F 5-46 \\
199-F-5-48 \\
199-F 6-1\end{array}$ & $\begin{array}{c}33.2(10 / 01) \\
265(2 / 00) \\
9.89(10 / 01) \\
7.38(10 / 01) \\
9.27(10 / 01) \\
\text { ND }(10 / 01) \\
\text { ND }(10 / 01)\end{array}$ & $\begin{array}{c}118.5(10 / 97) \\
429(10 / 97) \\
9.89(10 / 01) \\
8.61(10 / 98) \\
11.7(10 / 98) \\
8.54(11 / 95) \\
17.6(10 / 97)\end{array}$ & $\begin{array}{c}600 \\
650 \\
330 \\
125 \\
1,280 \\
2,150 \\
600\end{array}$ & $\begin{array}{l}\text { Source for F5-1 and F5-3 is } \\
\text { effluent disposed to liquid } \\
\text { waste disposal trench; F-46 is } \\
\text { isolated occurrence. } \\
\text { Concentrations are decreasing } \\
\text { over time. }\end{array}$ \\
\hline & $\begin{array}{l}\text { Trichloroethene } \\
\quad(5 \mu \mathrm{g} / \mathrm{L})\end{array}$ & $\begin{array}{c}199-F 5-45 \\
199-F 5-46 \\
199-F 7-1 \\
199-F 7-2 \\
199-F 7-3 \\
699-77-36\end{array}$ & $\begin{array}{l}3.5(10 / 00) \\
4.9(10 / 01) \\
18(10 / 01) \\
5.6(10 / 01) \\
4.9(10 / 00) \\
15(10 / 01)\end{array}$ & $\begin{array}{l}6(10 / 97) \\
7(4 / 93) \\
28(3 / 93) \\
6(6 / 94) \\
5(9 / 94) \\
29(3 / 92)\end{array}$ & $\begin{array}{l}1,780 \\
1,280 \\
5,450 \\
2,740 \\
4,850 \\
6,000\end{array}$ & $\begin{array}{l}\text { Not a risk driver, however, } \\
\text { exceeds standard of } 5 \text { Source is } \\
\text { west of } 100-\mathrm{F} \text { Area. }\end{array}$ \\
\hline & $\begin{array}{c}\text { Nitrate } \\
\left(\text { as } \mathrm{NO}_{3}^{-}\right) \\
(45,000 \mu \mathrm{g} / \mathrm{L})\end{array}$ & $\begin{array}{c}199-F 5-1 \\
199-F 5-3 \\
199-F 5-4 \\
199-F 5-45 \\
199-F 5-46 \\
199-F 5-47 \\
199-F 5-48 \\
199-F 7-1 \\
199-F 7-2 \\
199-F 7-3 \\
199-F 8-1^{c} \\
199-F 8-2 \\
199-F-8-3 \\
199-F 8-4\end{array}$ & $\begin{array}{c}20,800(10 / 01) \\
34,100(12 / 99) \\
116,000(1 / 01) \\
84,100(5 / 02) \\
54,900(10 / 01) \\
106,000(10 / 01) \\
34,300(10 / 01) \\
93,400(10 / 01) \\
70,800(10 / 01) \\
158,000(10 / 00) \\
109,000(9 / 97) \\
93,800(10 / 01) \\
39,800(10 / 00) \\
72,200(10 / 01)\end{array}$ & $\begin{array}{c}149,000(10 / 97) \\
65,100(10 / 97) \\
133,000(1 / 99) \\
109,000(1 / 99) \\
71,300(10 / 00) \\
131,000(10 / 98) \\
108,000(12 / 99) \\
287,000(10 / 97) \\
84,600(10 / 98) \\
158,000(10 / 00) \\
116,000(5 / 95) \\
100,000(5 / 95) \\
114,211(10 / 93) \\
106,000(9 / 97)\end{array}$ & $\begin{array}{c}600 \\
650 \\
2,410 \\
1,780 \\
1,280 \\
2,660 \\
2,150 \\
5,450 \\
2,740 \\
4,850 \\
3,200 \\
3,020 \\
3,820 \\
2,850\end{array}$ & $\begin{array}{l}\text { Widespread, multiple sources. } \\
\text { Concentrations are decreasing } \\
\text { over time except in 199-F5-46 } \\
\text { and 199-F7-3 (trend is } \\
\text { increasing) }\end{array}$ \\
\hline & $\begin{array}{c}\text { Tritium } \\
(20,000 \mathrm{pCi} / \mathrm{L})\end{array}$ & 199-F8-3 & $38,600(4 / 01)$ & $180,000(4 / 93)$ & 3,820 & $\begin{array}{l}\text { Possible source is fuel storage } \\
\text { basin effluent disposed to } \\
\text { liquid waste trench near } \\
\text { reactor. Decreasing trend }\end{array}$ \\
\hline & $\begin{array}{l}\text { Uranium } \\
(30 \mu \mathrm{g} / \mathrm{L})\end{array}$ & $199-F 8-1^{(a)}$ & $47.6(9 / 97)$ & $257.01(10 / 95)$ & 3,200 & $\begin{array}{l}\text { Possible source is fuel storage } \\
\text { basin sludge disposed to liquid } \\
\text { waste trench near reactor. }\end{array}$ \\
\hline & $\begin{array}{c}\text { Manganese }^{(b)} \\
(50 \mu \mathrm{g} / \mathrm{L})\end{array}$ & $\begin{array}{c}199-\mathrm{F} 5-3 \\
199-\mathrm{F} 5-43 \mathrm{~B} \\
199-\mathrm{F} 5-47 \\
199-\mathrm{F} 7-3\end{array}$ & $\begin{array}{l}11.2(12 / 99) \\
135(10 / 01) \\
\mathrm{ND}(10 / 01) \\
7.0(10 / 00)\end{array}$ & $\begin{array}{l}382(10 / 96) \\
243(12 / 99) \\
102(12 / 92) \\
90.4(1 / 93)\end{array}$ & $\begin{array}{c}650 \\
120 \\
2,660 \\
4,850\end{array}$ & $\begin{array}{l}\text { Common in Hanford } \\
\text { sediments. }\end{array}$ \\
\hline $\begin{array}{l}\text { (a) } \\
\text { (b) } \\
\text { (c) }\end{array}$ & $\begin{array}{l}\text { Arsenic, chromium, } \\
\text { lead are constituent } \\
\text { not detected in the } 1 \\
\text { Filtered analysis. } \\
\text { Well was decommi }\end{array}$ & $\begin{array}{l}\text { Iganese, nitrate } \\
\text { potential conce } \\
\text { ork monitoring } \\
\text { ed. }\end{array}$ & $\begin{array}{l}\text { ntium-90, and triti } \\
\text { ecological recepto } \\
\text { 00-F Area. Samp }\end{array}$ & $\begin{array}{l}\text { constituents of c } \\
\text { iver environment } \\
\text { re not analyzed fo }\end{array}$ & $\begin{array}{l}\text { for human } \\
\text { e: Peterson } \\
\text { and arsenic }\end{array}$ & $\begin{array}{l}\text { lth risk; chromium, copper, and } \\
\text { al. 1996). Copper is essentially } \\
\text { er 1995. }\end{array}$ \\
\hline
\end{tabular}


Table A.4. Statistical Summary for Wells in 100-B/C Area Where Groundwater Quality Standards Were or Still Are Exceeded

\begin{tabular}{|c|c|c|c|c|c|c|c|c|}
\hline \multirow[b]{2}{*}{ Well } & \multirow[b]{2}{*}{ Period } & \multirow{2}{*}{$\begin{array}{c}\text { No. of } \\
\text { Analyses }\end{array}$} & \multirow{2}{*}{$\begin{array}{l}\text { No. of } \\
\text { Detects }\end{array}$} & \multirow{2}{*}{$\begin{array}{l}\text { No. of } \\
\text { Non- } \\
\text { Detect }\end{array}$} & \multicolumn{3}{|c|}{ Detected Value } & \multirow{2}{*}{$\begin{array}{c}\text { No. of } \\
\text { Excluded } \\
\text { Value }\end{array}$} \\
\hline & & & & & Minimum & Maximum & Average & \\
\hline \multicolumn{9}{|c|}{ Strontium-90 (GWQ Standard $=8 \mathrm{pCi} / \mathrm{L})$} \\
\hline 199-B3-1 & $5 / 92-1 / 02$ & 25 & 25 & 0 & 38.2 & 68 & 49.4 & 0 \\
\hline 199-B3-46 & $7 / 92-1 / 02$ & 26 & $24^{(\mathrm{a})}$ & 0 & 33.5 & 150 & 72.6 & 2 \\
\hline 199-B3-47 & $7 / 92-1 / 02$ & 26 & 26 & 0 & 17.4 & 39.1 & 23.8 & 0 \\
\hline 199-B4-1 & $5 / 92-2 / 00$ & 17 & $16^{(\mathrm{a})}$ & 0 & 14.8 & 23 & 20.2 & 1 \\
\hline 199-B4-4 & $5 / 92-1 / 01$ & 17 & 17 & 0 & 15.4 & 34.8 & 28.1 & 0 \\
\hline 199-B4-7 & $2 / 92-1 / 02$ & 13 & 13 & 0 & 3.76 & 8.89 & 6.3 & 0 \\
\hline 199-B4-9 & $7 / 92-2 / 01$ & 15 & 15 & 0 & 19.8 & 36.3 & 27.0 & 0 \\
\hline 199-B5-2 & $7 / 92-1 / 02$ & 16 & 16 & 0 & 13.8 & 32.5 & 17.9 & 0 \\
\hline \multicolumn{9}{|c|}{ Tritium (GWQ Standard $=20,000 \mathrm{pCi} / \mathrm{L}$ ) } \\
\hline 199-B3-1 & $5 / 92-1 / 02$ & 17 & $16^{(\mathrm{a})}$ & 0 & 2,630 & 70,100 & 12,100 & 1 \\
\hline 199-B3-47 & $7 / 92-1 / 02$ & 18 & $17^{(\mathrm{a})}$ & 0 & 3,850 & 88,100 & 33,500 & 1 \\
\hline 199-B5-1 & $7 / 92-1 / 02$ & 22 & $20^{(\mathrm{a})}$ & 0 & 1,080 & 41,700 & 11,200 & 2 \\
\hline 199-B5-2 & $7 / 92-1 / 02$ & 15 & 15 & 0 & 3,200 & 420,000 & 44,900 & 0 \\
\hline 199-B8-6 & $7 / 92-1 / 02$ & 16 & 16 & 0 & 1,500 & 91,900 & 22,100 & 0 \\
\hline $699-65-72$ & 2/92-3/02 & 22 & $18^{(a)}$ & 3 & 291 & 28,000 & 17,200 & 1 \\
\hline \multicolumn{9}{|c|}{ Filtered Chromium $(G W Q$ Standard $=100 \mu \mathrm{g} / \mathrm{L})$} \\
\hline 199-B5-1 & $7 / 92-1 / 01$ & 22 & 22 & 0 & 11.8 & 113 & 54.5 & 0 \\
\hline \multicolumn{9}{|c|}{ Hexavalent Chromium (Ambient Water Quality Criteria= $22 \mu \mathrm{g} / \mathrm{L}$ ) } \\
\hline 199-B3-47 & $6 / 97-1 / 02$ & 12 & 12 & 0 & 21 & 151 & 63.9 & 0 \\
\hline 199-B5-1 & $6 / 97-1 / 02$ & 11 & 10 & 1 & 10 & 140 & 65.5 & 0 \\
\hline \multicolumn{9}{|c|}{ Filtered Aluminum (GWQ Standard $=50 \mu \mathrm{g} / \mathrm{L})$} \\
\hline 199-B2-12 & $7 / 92-1 / 02$ & 18 & 5 & 13 & 25.2 & 99.2 & 48.2 & 0 \\
\hline 199-B3-46 & $7 / 92-1 / 02$ & 17 & 5 & 12 & 21.2 & 85.4 & 42.3 & 0 \\
\hline 199-B4-5 & $7 / 92-1 / 02$ & 16 & $4^{(\mathrm{a})}$ & 11 & 20.4 & 52 & 37.7 & 1 \\
\hline \multicolumn{9}{|c|}{ Filtered Iron (GWQ Standard $=300 \mu \mathrm{g} / \mathrm{L})$} \\
\hline 199-B3-1 & $5 / 92-1 / 02$ & 15 & 10 & 5 & 10.8 & 305 & 91.7 & 0 \\
\hline 199-B3-46 & $7 / 92-1 / 02$ & 17 & 11 & 6 & 11 & 470 & 83.2 & 0 \\
\hline 199-B4-5 & $2 / 92-1 / 02$ & 17 & 12 & 5 & 7 & 676 & 107.6 & 0 \\
\hline 199-B4-9 & $7 / 92-2 / 01$ & 14 & 10 & 4 & 20.7 & 359 & 69.2 & 0 \\
\hline 199-B9-3 & $7 / 92-2 / 01$ & 12 & 9 & 3 & 7.6 & 644 & 149.2 & 0 \\
\hline
\end{tabular}


Table A.5. Statistical Summary for Wells in 100-F Area Where Groundwater Quality Standards Were or Still Are Exceeded

\begin{tabular}{|c|c|c|c|c|c|c|c|c|}
\hline \multirow[b]{2}{*}{ Well } & \multirow[b]{2}{*}{ Period } & \multirow{2}{*}{$\begin{array}{c}\text { No. of } \\
\text { Analyses }\end{array}$} & \multirow{2}{*}{$\begin{array}{l}\text { No. of } \\
\text { Detects }\end{array}$} & \multirow{2}{*}{$\begin{array}{l}\text { No. of } \\
\text { Non- } \\
\text { Detect }\end{array}$} & \multicolumn{3}{|c|}{ Detected Value } & \multirow{2}{*}{$\begin{array}{c}\text { No. of } \\
\text { Excluded } \\
\text { Value } \\
\end{array}$} \\
\hline & & & & & Minimum & Maximum & Average & \\
\hline \multicolumn{9}{|c|}{ Filtered Chromium (GWQ Standard $=100 \mu \mathrm{g} / \mathrm{L})$} \\
\hline 199-F5-46 & $2 / 92-10 / 01$ & 19 & 19 & 0 & 27.8 & 366 & 127.1 & 0 \\
\hline \multicolumn{9}{|c|}{ Hexavalent Chromium (Ambient Water Quality Criteria $=22 \mu \mathrm{g} / \mathrm{L}$ ) } \\
\hline 199-F5-46 & $10 / 97-1 / 02$ & 18 & 18 & 0 & 24 & 208 & 84.2 & 0 \\
\hline \multicolumn{9}{|c|}{ Strontium-90 (GWQ Standard $=8 \mathrm{pCi} / \mathrm{L})$} \\
\hline 199-F5-1 & $2 / 92-10 / 01$ & 35 & $34^{(\mathrm{a})}$ & 0 & 10.3 & 130 & 41.4 & 1 \\
\hline 199-F5-3 & $1 / 93-2 / 00$ & 17 & $15^{(\mathrm{a})}$ & 1 & 129 & 429 & 242.6 & 1 \\
\hline 199-F5-6 & $2 / 92-10 / 01$ & 21 & $18^{(\mathrm{a})}$ & 2 & 0.77 & 9.89 & 6.1 & 1 \\
\hline 199-F5-44 & $12 / 92-10 / 01$ & 13 & $11^{(\mathrm{a})}$ & 1 & 3.76 & 8.61 & 6.0 & 1 \\
\hline 199-F5-46 & $12 / 92-10 / 01$ & 19 & $18^{(\mathrm{a})}$ & 0 & 8.03 & 13 & 10.2 & 1 \\
\hline 199-F5-48 & $1 / 93-10 / 01$ & 15 & $3^{(a)}$ & 11 & 1.41 & 8.54 & 4.1 & 1 \\
\hline 199-F6-1 & $1 / 93-10 / 01$ & 13 & $5^{(\mathrm{a})}$ & 7 & 1.03 & 17.6 & 5.2 & 1 \\
\hline \multicolumn{9}{|c|}{ Trichloroethene (GWQ Standard $=5 \mu \mathrm{g} / \mathrm{L}$ ) } \\
\hline 199-F5-45 & $12 / 92-10 / 00$ & 16 & 16 & 0 & 1 & 6 & 3.68 & 0 \\
\hline 199-F5-46 & $12 / 92-10 / 01$ & 16 & 13 & 3 & 0.87 & 7 & 3.89 & 0 \\
\hline 199-F7-1 & $2 / 92-10 / 01$ & 23 & 23 & 0 & 9.9 & 28 & 20.3 & 0 \\
\hline 199-F7-2 & $1 / 93-10 / 01$ & 14 & 14 & 0 & 3 & 6 & 3.89 & 0 \\
\hline 199-F7-3 & $1 / 93-10 / 00$ & 17 & 16 & 1 & 0.5 & 5 & 2.84 & 0 \\
\hline $699-77-36$ & $3 / 92-10 / 01$ & 16 & 16 & 0 & 15 & 29 & 22.56 & 0 \\
\hline \multicolumn{9}{|c|}{ Nitrate $\left(\right.$ asNO $_{3}^{-}, \mathrm{GWQ}$ Standard $\left.=45,000 \mu \mathrm{g} / \mathrm{L}\right)$} \\
\hline 199-F5-1 & $2 / 92-10 / 01$ & 26 & 26 & 0 & 2,500 & 149,000 & 17,600 & 0 \\
\hline 199-F5-3 & $5 / 92-12 / 99$ & 9 & 8 & 1 & 300 & 65,100 & 19,300 & 0 \\
\hline 199-F5-4 & $2 / 92-1 / 01$ & 17 & 17 & 0 & 67,300 & 133,000 & 90,900 & 0 \\
\hline 199-F5-45 & $12 / 92-9 / 02$ & 30 & $29^{(\mathrm{a})}$ & 0 & 2,800 & 109,000 & 63,900 & 1 \\
\hline 199-F5-46 & $12 / 92-10 / 01$ & 21 & 21 & 0 & 9,000 & 71,300 & 46,200 & 0 \\
\hline 199-F5-47 & $12 / 92-10 / 01$ & 21 & 21 & 0 & 81,000 & 131,000 & 101,900 & 0 \\
\hline 199-F5-48 & $1 / 93-10 / 01$ & 13 & 13 & 0 & 34,100 & 108,000 & 68,900 & 0 \\
\hline 199-F6-1 & $1 / 93-10 / 01$ & 13 & 13 & 0 & 1,990 & 43,500 & 7,100 & 0 \\
\hline 199-F7-1 & $2 / 92-10 / 01$ & 24 & 24 & 0 & 8,850 & 287,000 & 106,900 & 0 \\
\hline 199-F7-2 & $1 / 93-10 / 01$ & 13 & 13 & 0 & 53,100 & 84,600 & 67,200 & 0 \\
\hline 199-F-7-3 & $1 / 93-10 / 00$ & 17 & 17 & 0 & 84,100 & 158,000 & 118,700 & 0 \\
\hline $199-F 8-1^{b}$ & $10 / 92-9 / 97$ & 6 & 6 & 0 & 93,000 & 116,000 & 104,800 & 0 \\
\hline 199-F8-2 & $2 / 92-10 / 01$ & 15 & 15 & 0 & 55,800 & 105,400 & 87,900 & 0 \\
\hline 199-F8-3 & $12 / 92-10 / 00$ & 10 & 10 & 0 & 5,900 & 114,200 & 73,500 & 0 \\
\hline 199-F8-4 & $1 / 93-10 / 01$ & 17 & 17 & 0 & 72,200 & 111,600 & 96,900 & 0 \\
\hline \multicolumn{9}{|c|}{ Tritium (GWQ Standard = 20,000 pCi/L) } \\
\hline 199-F8-3 & $12 / 92-4 / 01$ & 14 & $13^{(\mathrm{a})}$ & 0 & 16,300 & 180,000 & 77,600 & 1 \\
\hline \multicolumn{9}{|c|}{ Uranium (GWQ Standard $=30 \mu \mathrm{g} / \mathrm{L}$ ) } \\
\hline $199-\mathrm{F} 8-1^{\mathrm{b}}$ & $10 / 92-9 / 97$ & 5 & 5 & 0 & 27.7 & 257 & 101.1 & 0 \\
\hline \multicolumn{9}{|c|}{ Filtered Manganese (GWQ Standard $=50 \mu \mathrm{g} / \mathrm{L}$ ) } \\
\hline 199-F5-3 & $1 / 93-12 / 99$ & 7 & 6 & 1 & 0.72 & 382 & 79.2 & 0 \\
\hline 199-F5-43B & $5 / 95-10 / 01$ & 7 & 7 & 0 & 135 & 243 & 191.4 & 0 \\
\hline 199-F5-47 & $12 / 92-10 / 01$ & 16 & 10 & 6 & 2.3 & 105 & 21.0 & 0 \\
\hline 199-F7-3 & $1 / 93-10 / 00$ & 12 & 12 & 0 & 4.2 & 90.4 & 27.8 & 0 \\
\hline
\end{tabular}




\section{A.4.1.1 100-B/C-5}

Currently, hexavalent chromium is above the $22 \mu \mathrm{g} / \mathrm{L}$ ambient water quality criteria in two wells (199-B3-47 and 199-B5-1) and is of concern for ecological risk. Strontium and tritium remain slightly elevated in several wells of the 100-B/C Area. Highest concentrations of strontium-90 are obtained from samples collected in wells 199-B3-1 (38.2 pCi/L) and 199-B4-46 (39.3 pCi/L) during January 2002 sampling event. Currently, tritium exceeds $20,000 \mathrm{pCi} / \mathrm{L}$ standard in two wells $199-\mathrm{B} 3-47$ (30,600 pCi/L) and well 199-B8-6 (26,700 pCi/L). The tritium plume that originated from the 200 East Area has reached in the 100-B/C Area as indicated by monitoring results for well 699-72-73 (Table A.2). Carbon-14 and technetium-99 concentrations were well below standards and were removed from the monitoring schedule after 1995. Aluminum, iron, and nickel (ecological risk) no longer exceed standards in 100-B/C Area wells.

In addition to the constituents identified above, other constituents of potential concern to the $100-\mathrm{B} / \mathrm{C}$ Area include residual hazardous chemicals (e.g., lead, cadmium, mercury, and antimony) common to older reactor (DOE 2001). However, these constituents were essentially not detected in groundwater at 100-B/C-5 network wells and samples were not analyzed for lead after 1995.

\section{A.4.1.2 100-FR-3}

Currently, hexavalent chromium is above $22 \mu \mathrm{g} / \mathrm{L}$ ambient water quality criteria in one well (199-F5-46) and is of concern for ecological risk. Strontium-90 and nitrate remain elevated and exceed the drinking water standards in several wells. The highest concentration of strontium-90 is observed in well 199-F-3 (265 pCi/L, measured on February 2000), as in the past. Nitrate is widespread from multiple sources. Tritium exceeds standard in one well 199-F8-3 (38,600 pCi/L, measurement date April 2001). Manganese exceeds standard in 199-F5-43B (135 $\mu \mathrm{g} / \mathrm{L}$, measurement date October 2001). Copper is essentially not detected in the 100-FR-3 monitoring network. Lead and arsenic no longer exceeded the standards and were not analyzed after 1995. Trichloroethene, while not a risk driver, remains above standard in two wells (699-77-36 and 199-F7-2), as in the past. The source is believed west of the 100-F Area.

In addition to the constituents identified above, other constituents of potential concern at the 100-FR-3 Operable Unit include residual hazardous chemicals (e.g., cadmium, and mercury) common to older reactor and hazardous materials (e.g., asbestos) used in older buildings (DOE 2001). Asbestos is not expected to be present in groundwater and therefore is not analyzed. Cadmium and mercury were essentially not detected in groundwater in the wells monitoring the 100-BC-5 Operable Unit and samples were not analyzed for mercury after 1995 .

\section{A.4.3 Sources of Groundwater Contamination}

The $100-\mathrm{B} / \mathrm{C}$ Area is the area associated with operations of the B and C Reactors, which historically produced special nuclear material. Contamination resulted from uncontained releases or radioactive materials and hazardous chemicals. Typical contamination sources were (1) water treatment chemicals required to clean the river water prior to its use as a reactor coolant; (2) cooling water discharged from the 
reactor, which was contaminated with radionuclides; (3) fuel storage basin water and sludge from contamination by leaky irradiated reactor fuel; (4) chemicals used to decontaminate other materials and equipment; (5) septic system waste; and (6) disposal of paints and solvents.

The greatest volume of liquid waste at 100-B/C Area was associated with the retention basins and effluent pipelines that lead to the basins from the 105-B reactor building. These facilities handled reactor coolant effluent that contained radionuclides and hexavalent chromium. Significant leakage of this effluent occurred from the pipelines and the retention basins. Although short-lived radionuclides in the leakage decayed away quickly, long-lived radionuclides were retained on the sediment in the soil column. Hexavalent chromium moved unimpeded downward through the soil column and into the underlying groundwater.

There are 71 soil waste sites in the 100-F Area, including inactive burial grounds and liquid effluent management sites (e.g., basins, cribs, trenches, septic sites, unplanned releases, and animal farm waste disposal sites). These sites are all associated with operations of the F Reactor and are located in close proximity to the Columbia River. Contamination of groundwater occurred as the result of liquid effluent disposal associated with past reactor operations and from solid waste disposed in burial grounds.

\section{A.4.3 Contaminant Distribution Maps and Trend Charts}

\section{A.4.3.1 100-B/C Area}

Current (FY 2001) plume maps for strontium-90 and tritium concentrations have been plotted in Figure A.1. For comparison purposes, historical distributions of these constituents for FY2000 and FY1998 are presented in Figure A.2 and A.3, respectively. The concentrations plotted are average values of data from HEIS that have undergone the data evaluation process by the project scientist. This process is intended to produce concentration values that represent aquifer conditions. Although historically chromium was elevated in some wells in the 100-B/C Area (see Table A.2), contour lines are not generated for chromium for FY 2001 (FY 2000 and FY 1998) because average chromium concentrations were below the MCL of $100 \mu \mathrm{g} / \mathrm{L}$. The maps also include water-table contours. Groundwater flow is generally oriented perpendicular to the contour lines.

Strontium-90 is slightly elevated in an area extending from the 105-B reactor building downgradient to the river (see Figures A.1 to A.3). As noted earlier, the highest values currently observed in wells 199-B3-1 and 199-B3-46 appear to be residual contamination associated with the liquid waste disposal trenches. Strontium trend plots in selected wells are presented in Figure A.4.

Chromium (hexavalent) is slightly elevated above the Ambient Water Quality Criteria (AWQC) of $22 \mu \mathrm{g} / \mathrm{L}$ in two areas (Figure A.5). The first is near the river on the downgradient side of the retention basins in well 199-B3-47 (26 $\mu \mathrm{g} / \mathrm{L})$. The second area of elevated chromium is downgradient of former water treatment facilities where coolant water was prepared; a process included the addition of sodium dichromate. Sodium dichromate may have leaked from storage tanks and transfer facilities. The single monitoring well in this area (well 199-B5-1) shows highly fluctuating results, the cause for which is unknown. 


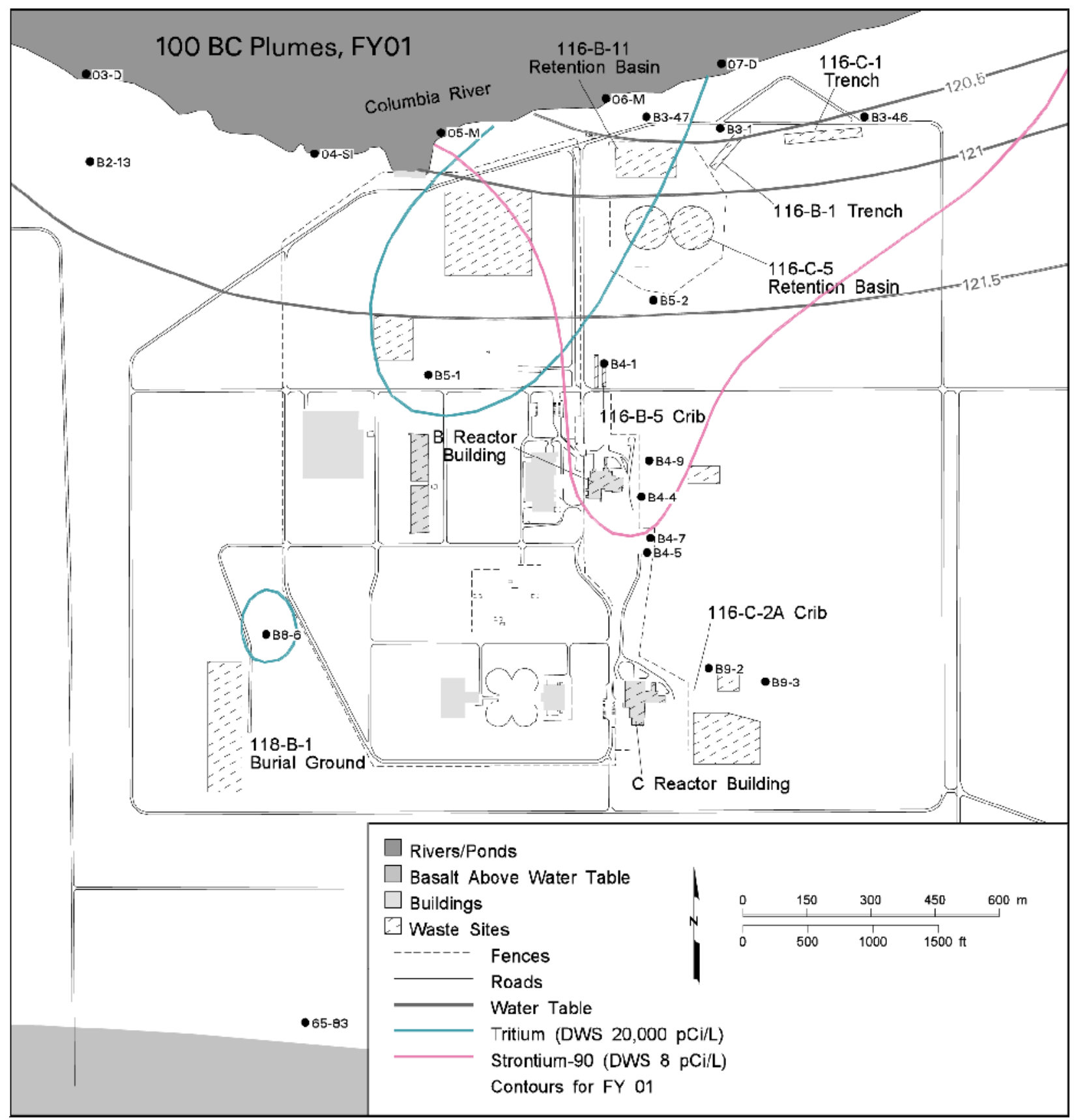

can chouc2 17 October 30,2002 11:43 AM

Figure A.1. Strontium-90 and Tritium Distribution in the 100-B/C Area, FY 2001 


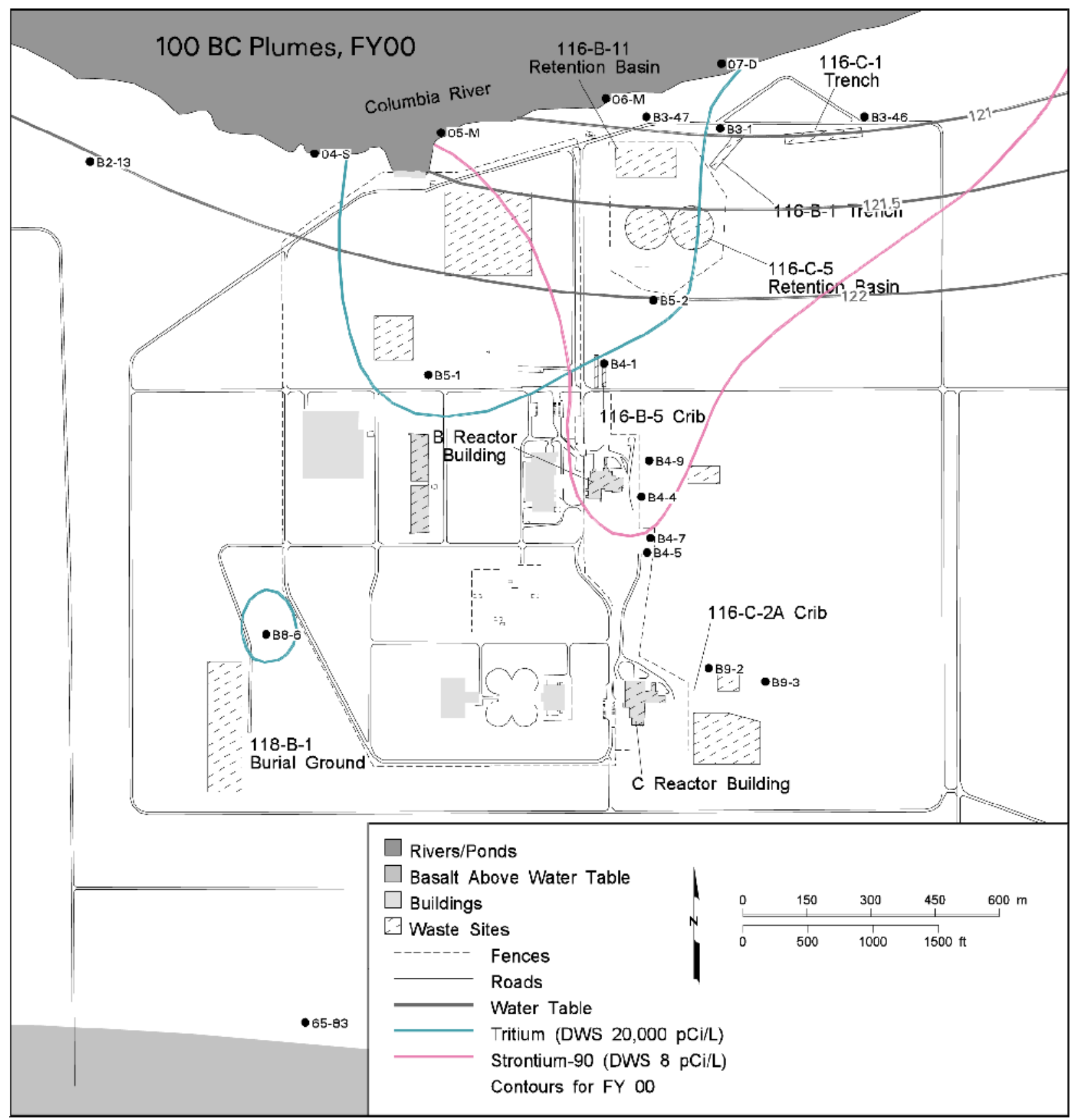

can chouc2 19 October 30,2002 11:48 AM

Figure A.2. Strontium-90 and Tritium Distribution in the 100-B/C Area, FY 2000 


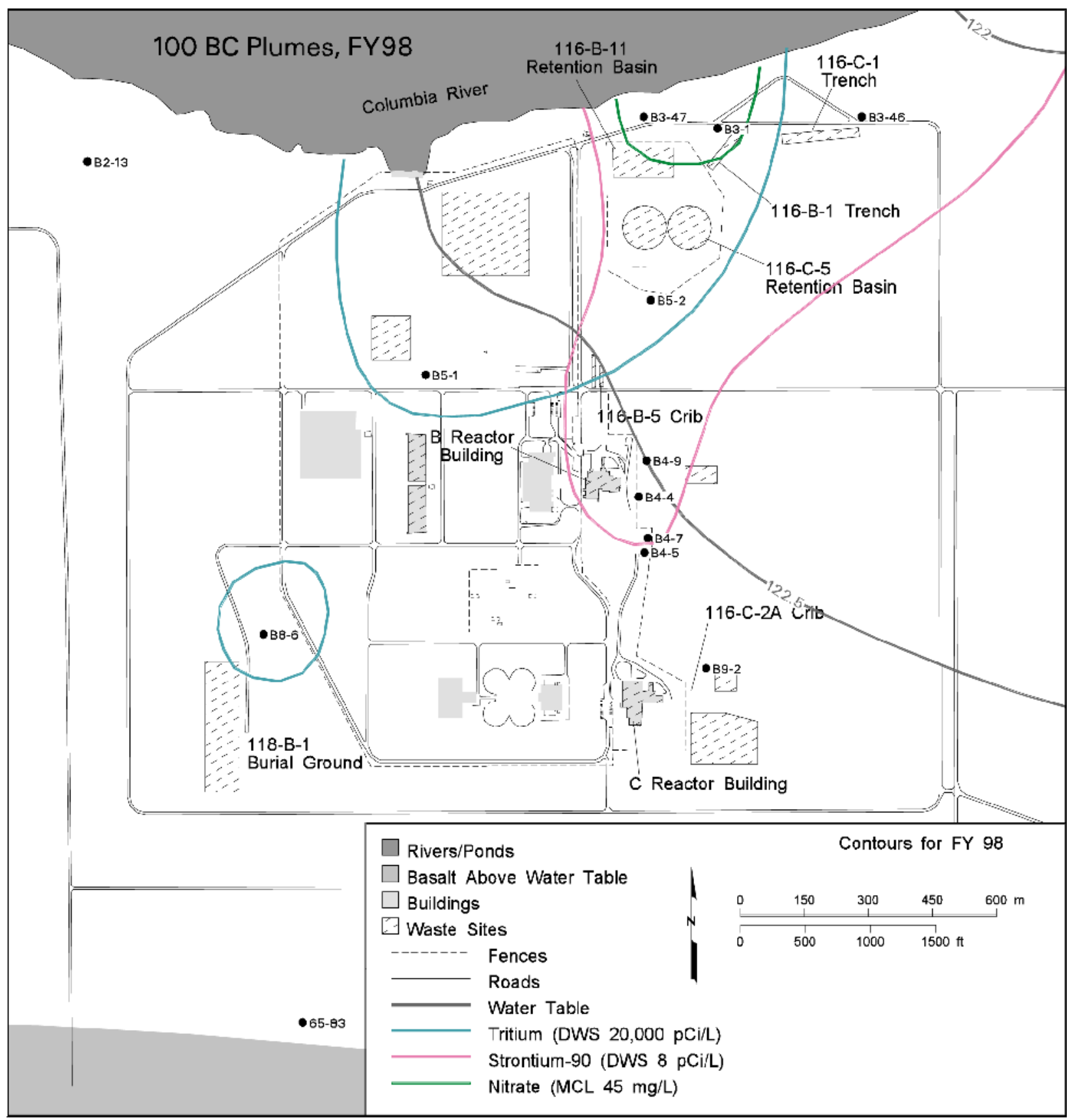

can chou02 21 October 30,2002 11:48 AM

Figure A.3. Strontium-90, Tritium and Nitrate Distribution in the 100-B/C Area, FY 1998 
199-B3-1 Strontium-90 (pCi/L)

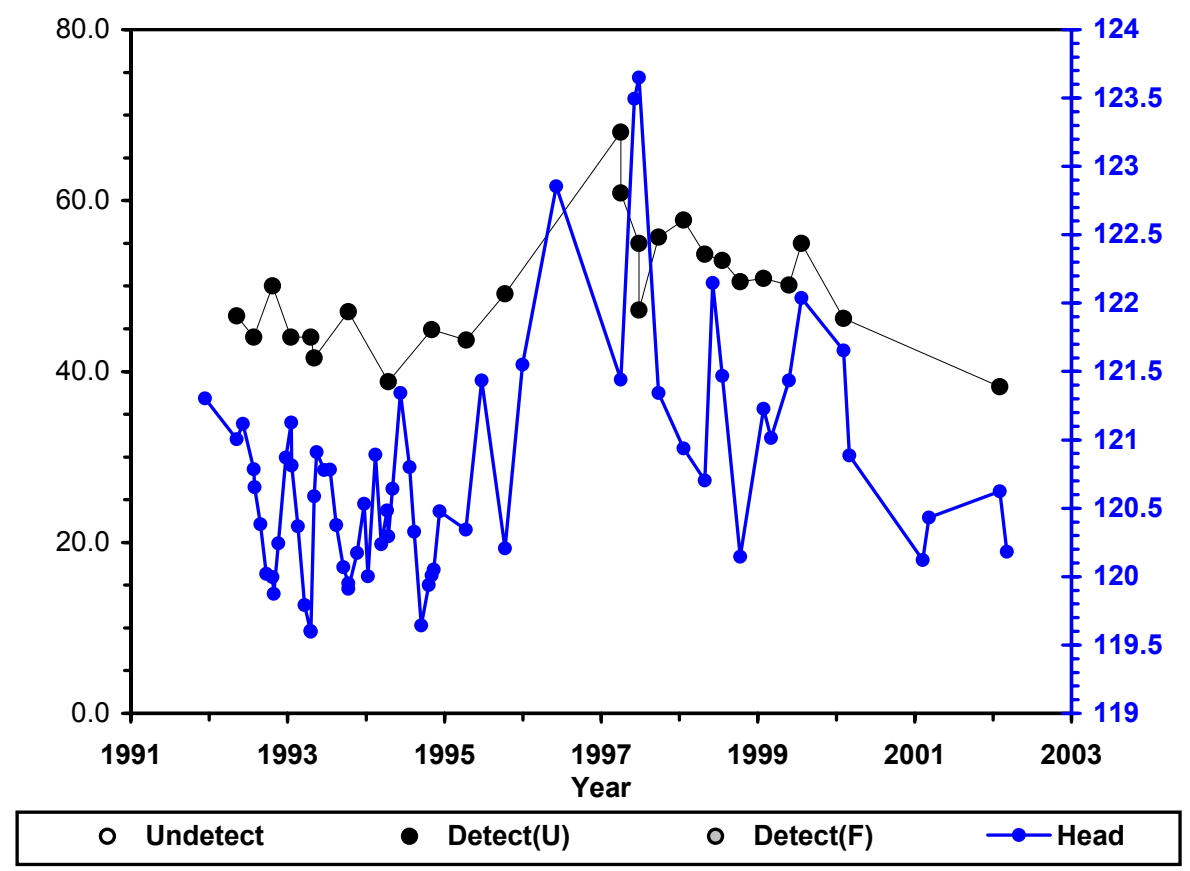

199-B3-46 Strontium-90 (pCi/L)

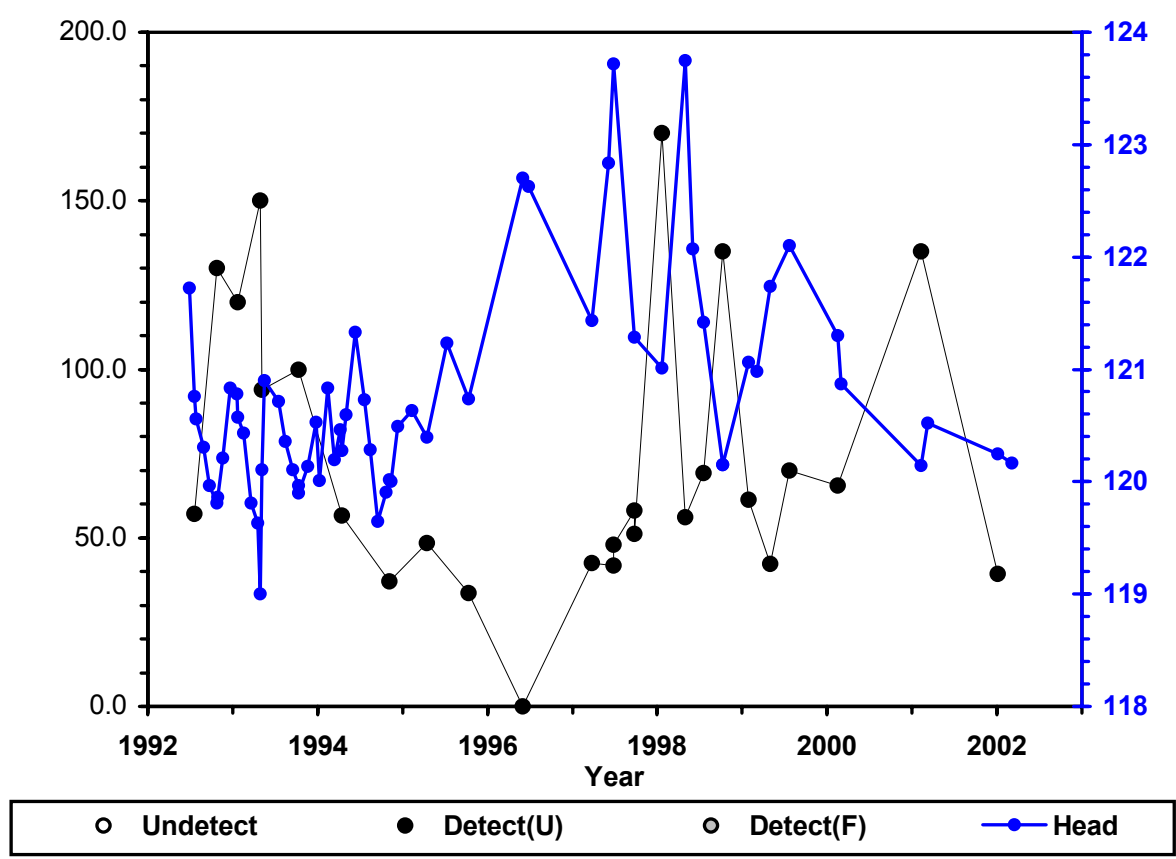

Figure A.4. Strontium-90 Trends in Selected 100-B/C Area-River Wells 
199-B3-47 Hexavalent Chromium (ug/L)

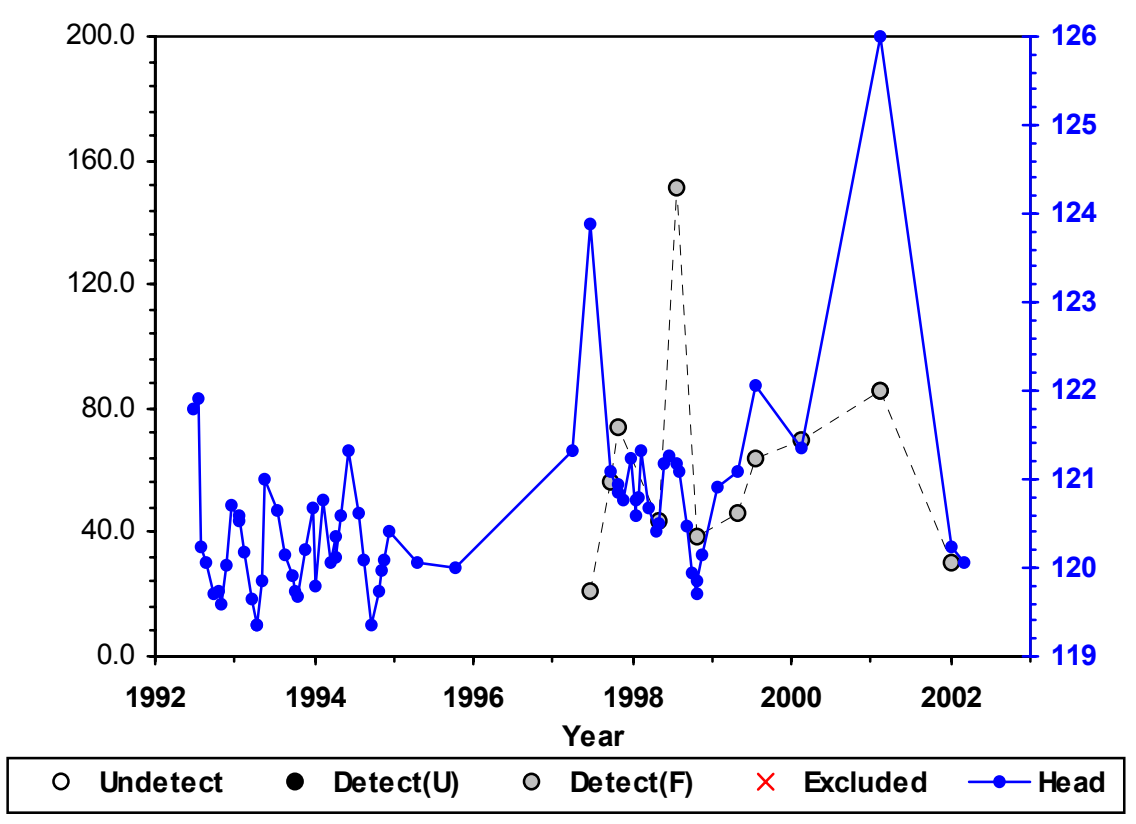

199-B5-1 Hexavalent Chromium (ug/L)

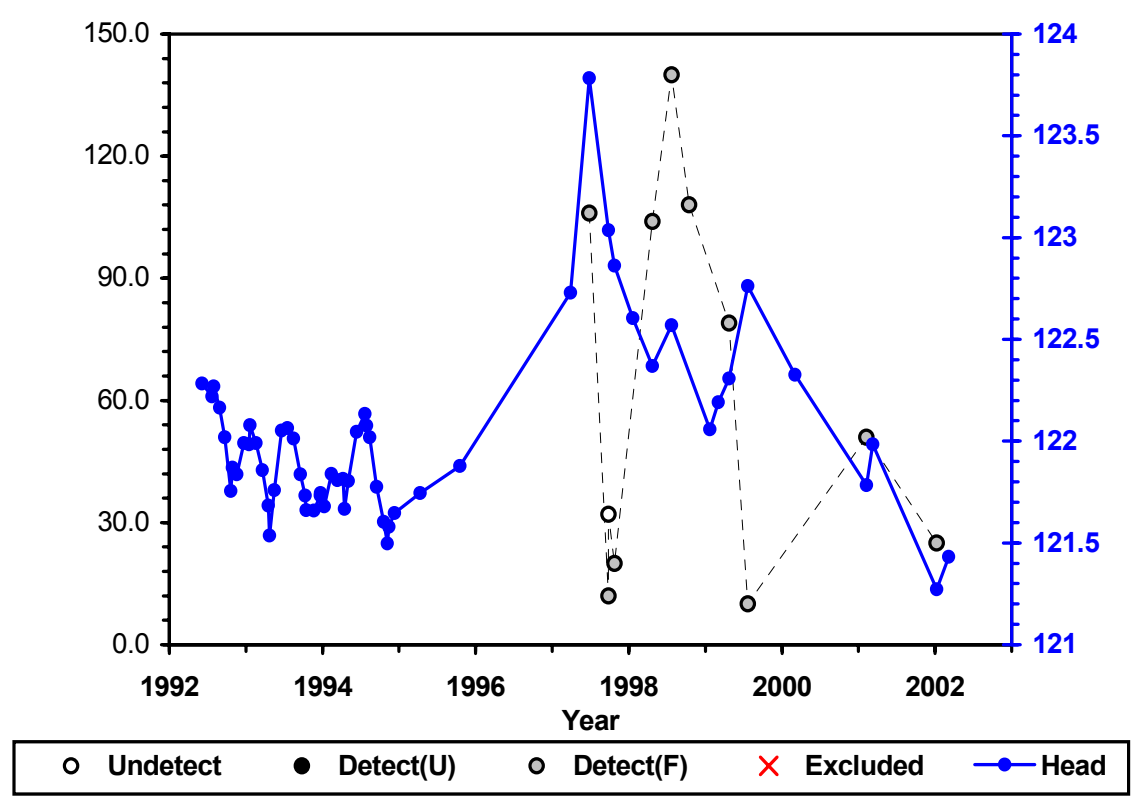

Figure A.5. Chromium Trends in Selected 100-B/C Area Wells 


\section{A.4.3.2 100-F Area}

Similar to the 100-B/C Area, current (i.e., FY 2001) plume maps for 100-F Area constituents of concern (chromium, nitrate, strontium-90, trichloroethene concentrations, and tritium) have been plotted in Figure A.6. For comparison purposes, prior year's plume maps (FY 2000 and FY 1998) are presented in Figures A.7 and A.8. The concentrations plotted are average values of data from HEIS that have undergone the data evaluation process by the project scientist. Chromium results are for filtered samples, since these data provide the best indicator of chromium that is dispersed by groundwater flow. Contour lines are not generated for chromium for FY 2001 and FY 1998 because average chromium concentrations were below the maximum contaminant level of $100 \mu \mathrm{g} / \mathrm{L}$. The maps also include water table contours. Groundwater flow is generally oriented perpendicular to the contour lines.

Strontium-90 is elevated in the area around the retention basin and liquid waste disposal trench (Figures A.6 through A.8). The highest value (429 pCi/L in 199-F5-3, see Table A.5) appears to be residual contamination associated with the trench. Concentration trend plots for this well and adjacent wells are shown in Figure A.9.

A widespread plume of chromium is not present in the $100 \mathrm{~F}$ Area, and concentrations in near-river wells are near detection level and below the AWQC of $22 \mu \mathrm{g} / \mathrm{L}$. A hot spot is present in well 199-F5-46. Concentration trends of chromium and hexavalent chromium for this well are shown in Figure A.10.

Trichloroethene is elevated in two wells in the southwest/west corner of the 100-F Area (wells 199-F7-1 and 699-77-36). Trend charts fro these two wells are shown in Figure A.11. The source of trichloroethene is believed to be to the west and northwest of these wells, and not associated with 100-F Area operations (DOE/RL 1995).

Nitrate trends for selected wells are shown in Figure A.12, and include wells 199-F5-46 and 199-F7-3. Both wells have shown distinct upward trends since 1997, the cause for which is uncertain. 


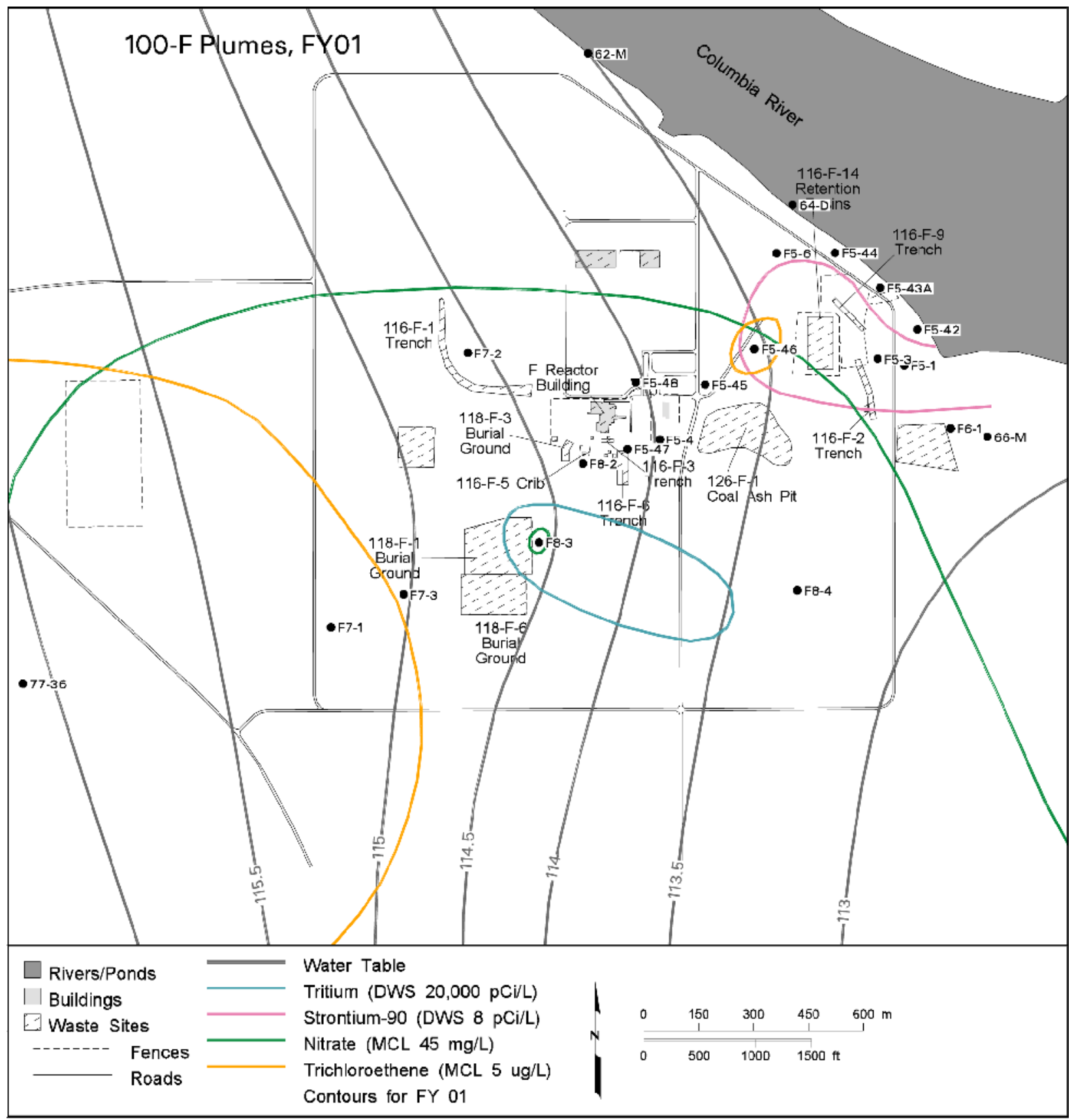

can chou02 18 October 30, 2002 12:19 PM

Figure A.6. Strontium-90, Nitrate, Tritium, and Trichloroethene Distribution in the 100 F Area, FY 2001 


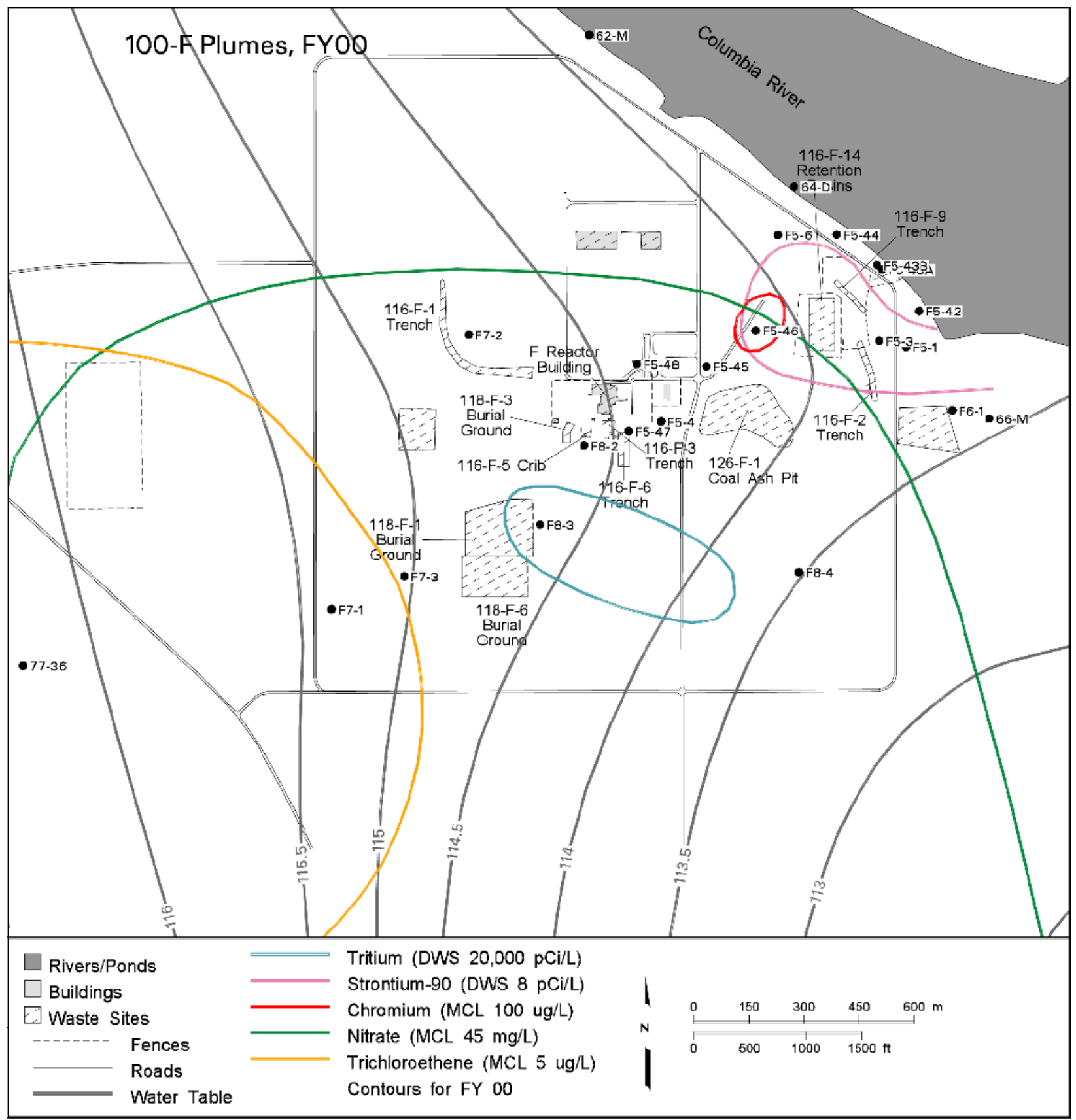

can chouO2 20 October 30, 2002 12:08 PM

Figure A.7. Strontium-90, Chromium, Nitrate, Tritium, and Trichloroethene Distribution in the 100 F Area, FY 2000 


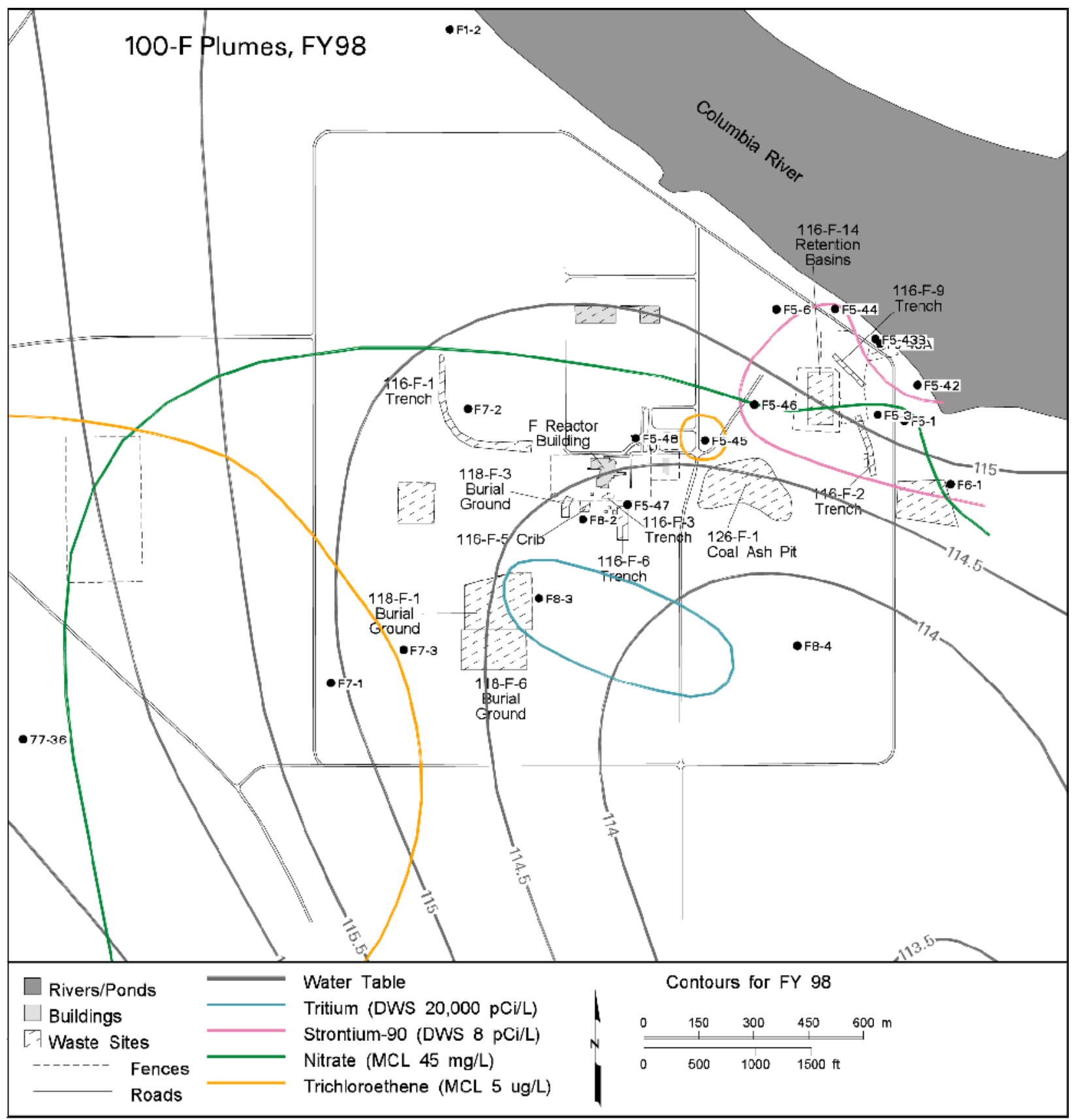

can chou02 22 October 30, 2002 11:48 AM

Figure A.8. Strontium-90, Nitrate, Tritium, and Trichloroethene Distribution in the 100 F Area, FY 1998 
199-F5-1 Strontium-90 (pCi/L)

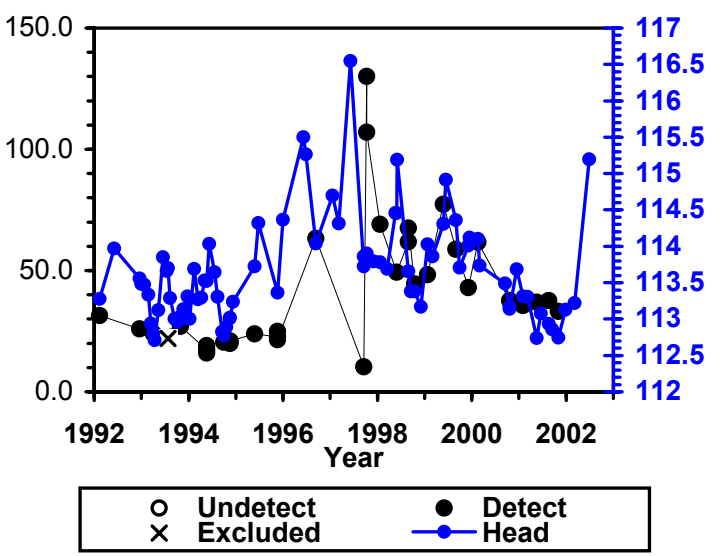

199-F5-6 Strontium-90 (pCi/L)

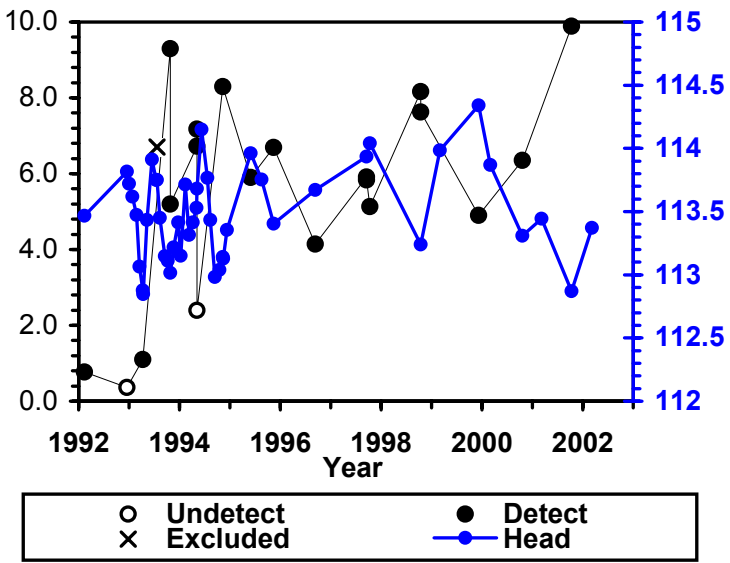

199-F5-44 Strontium-90 (pCi/L)

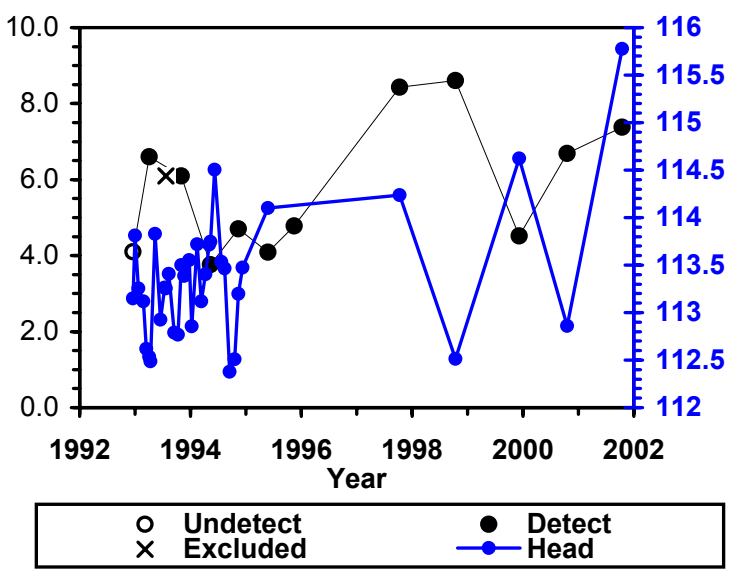

199-F5-3 Strontium-90 (pCi/L)

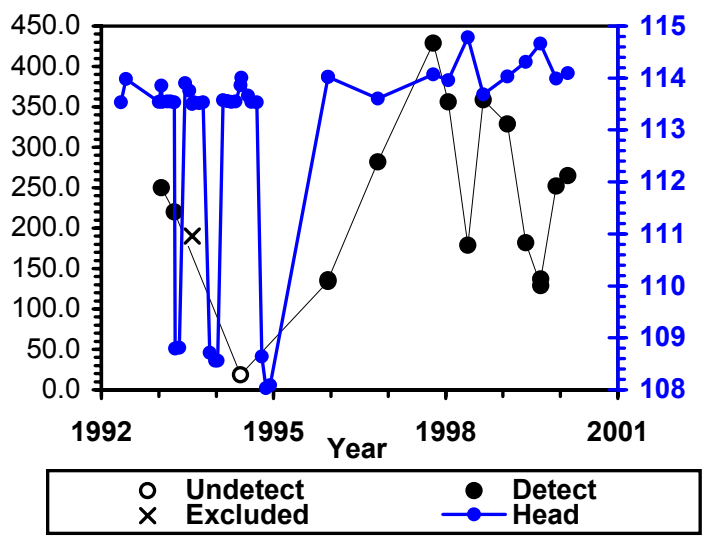

199-F5-46 Strontium-90 (pCi/L)

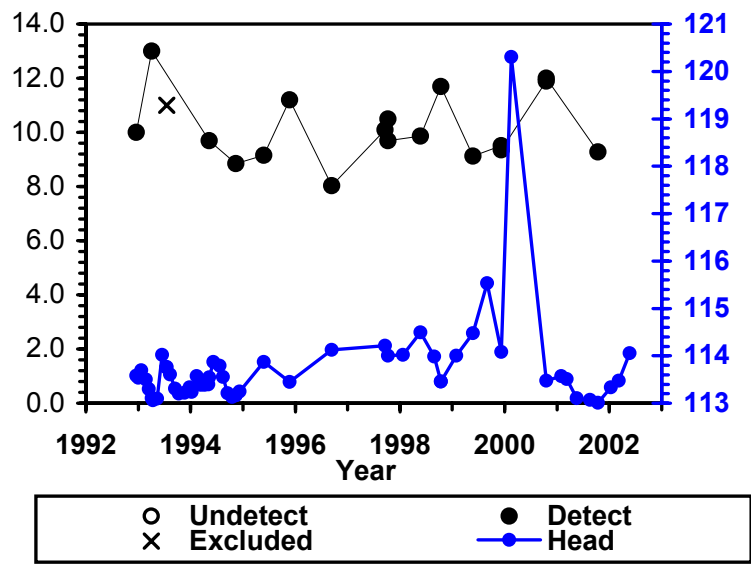

199-F6-1 Strontium-90 (pCi/L)

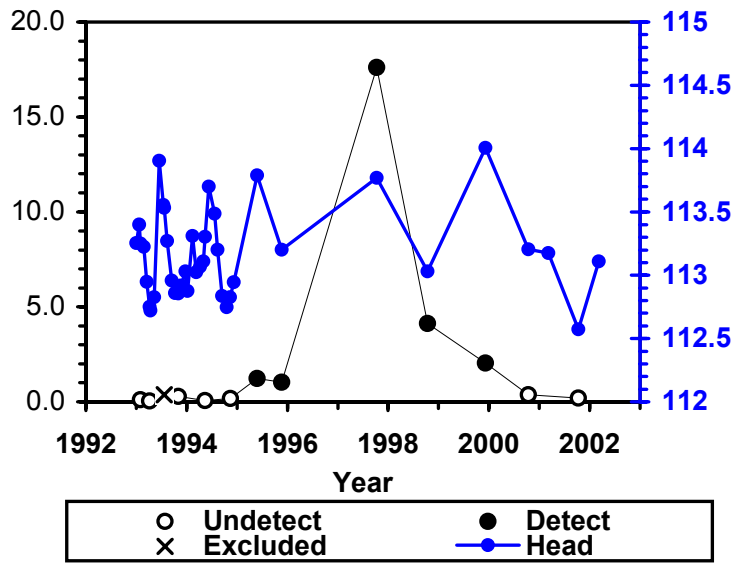

Figure A.9. Strontium-90 in Selected 100-F Area Wells 
199-F5-46 Chromium (ug/L)

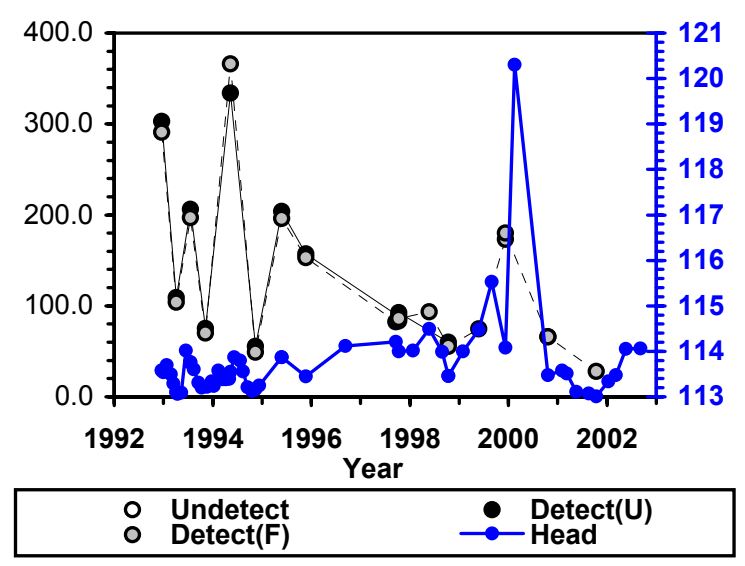

199-F5-46 Hexavalent Chromium

(ug/L)

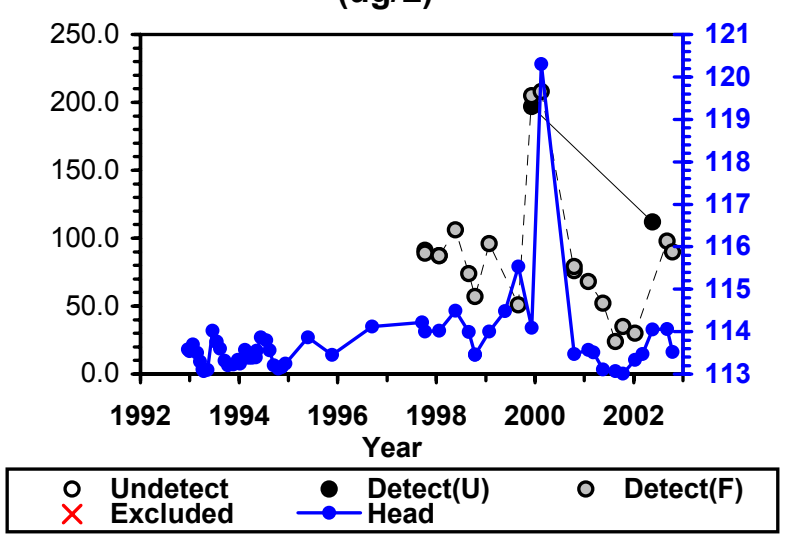

Figure A.10. Chromium Trends in Well 199-F5-46 in the 100-F Area

199-F7-1 Trichloroethene (ug/L)

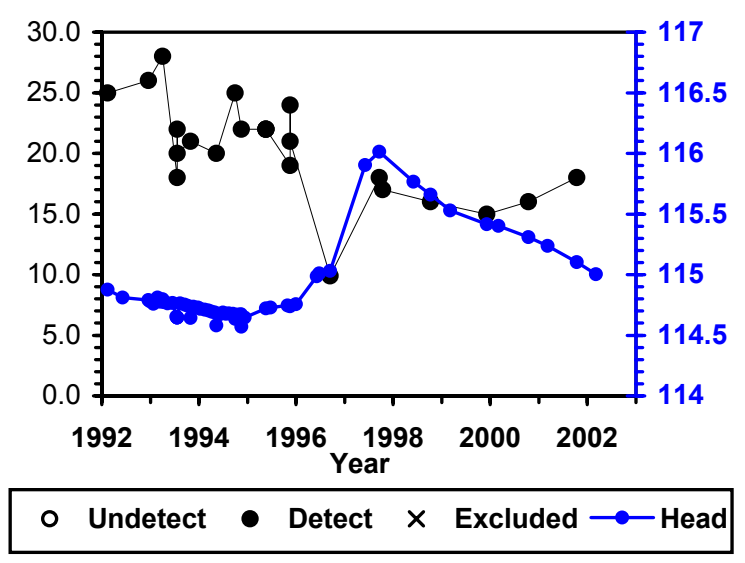

699-77-36 Trichloroethene (ug/L)

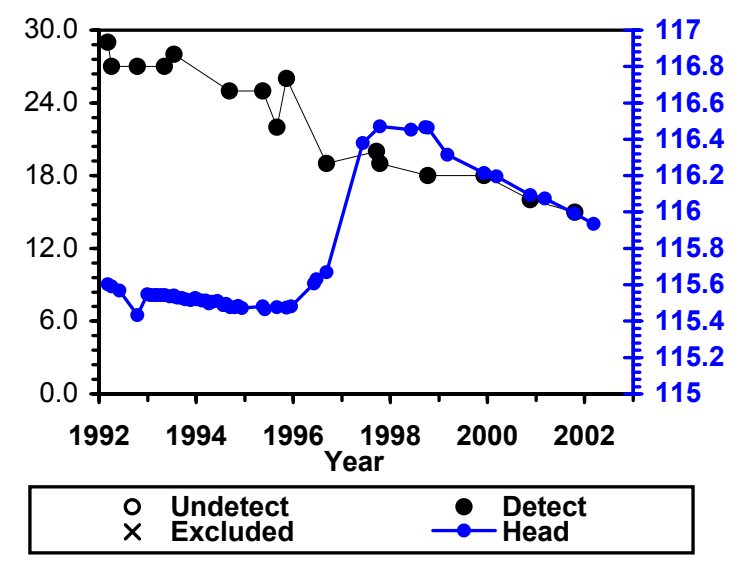

Figure A.11. Trichloroethene Trends in Selected 100-F Area Wells 
199-F5-45 Nitrate (ug/L)

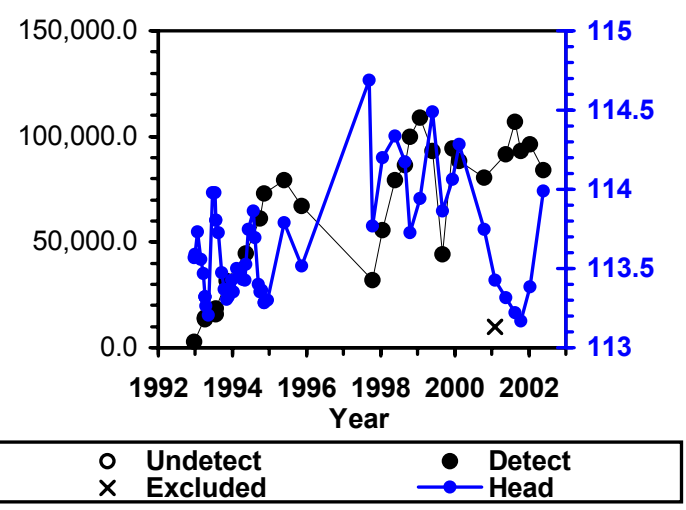

199-F5-47 Nitrate (ug/L)

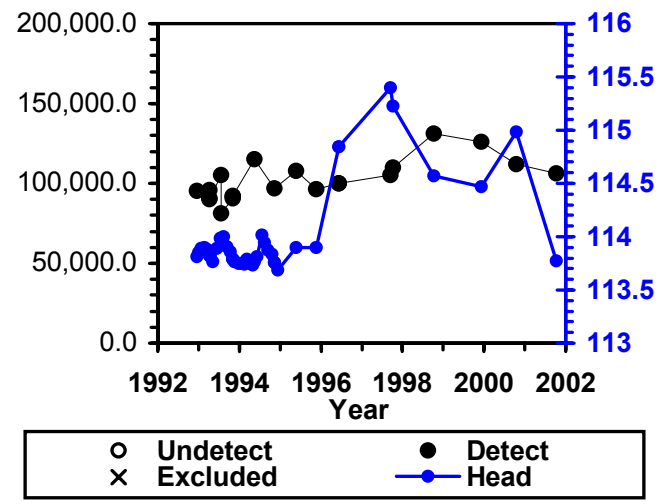

199-F7-3 Nitrate (ug/L)

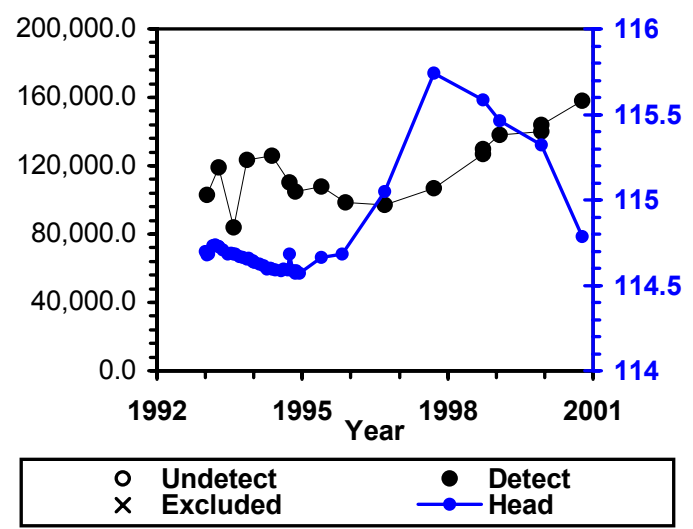

199-F5-46 Nitrate (ug/L)

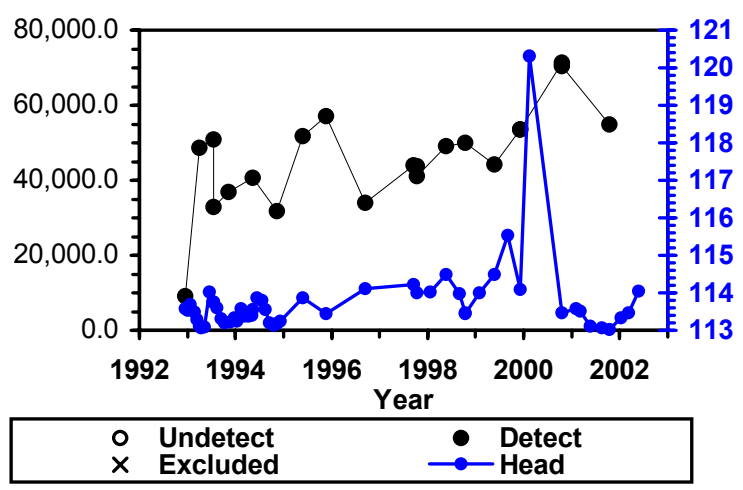

199-F7-1 Nitrate (ug/L)

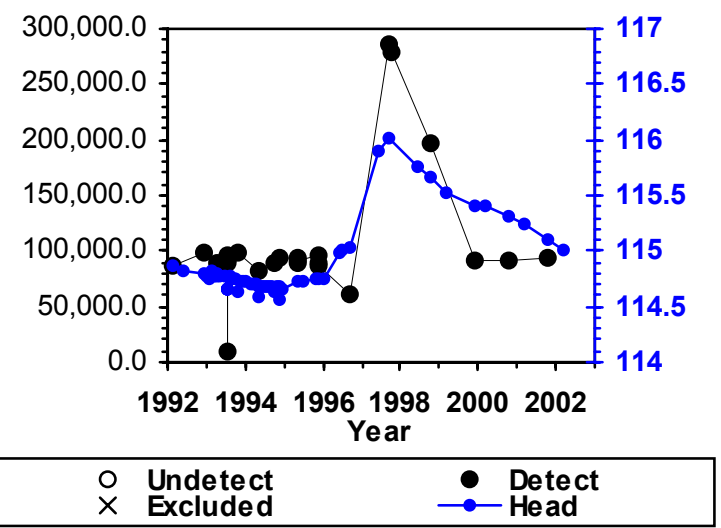

199-F8-2 Nitrate (ug/L)

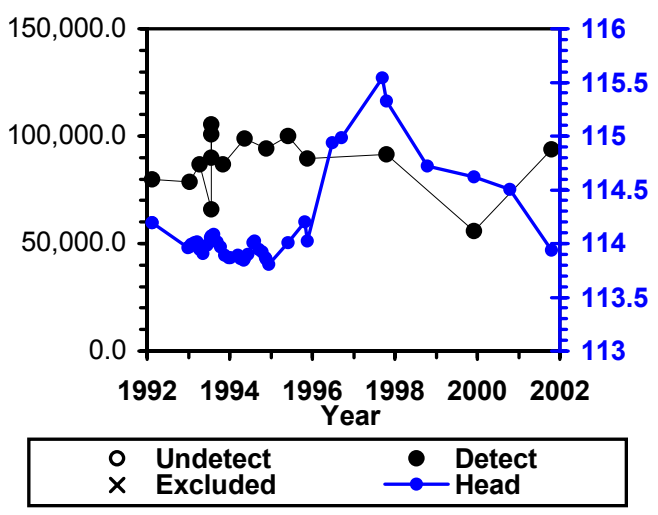

Figure A.12. Nitrate Trends in Selected 100-F Area Wells 


\section{A.5 References}

40 CFR 41. U.S. Environmental Protection Agency. "National Primary Drinking Water Regulations." Code of Federal Regulations.

DOE. 2001. A Report to Congress on Long-Term Stewardship: Volume II-Site Summaries.

DOE/EM-0563, Office of Environmental Management, U.S. Department of Energy, Germantown, Maryland.

DOE/RL. 1994a. Limited Field Investigation Report for the 100-BC-5 Operable Unit. DOE/RL-93-97, Rev. 0, U.S. Department of Energy, Richland Operations Office, Richland, Washington.

DOE/RL. 1994b. Limited Field Investigation Report for the 100-FR-3 Operable Unit. DOE/RL-93-83, Rev. 0, U.S. Department of Energy, Richland Operations Office, Richland, Washington.

DOE/RL. 1995. 100-FR-3 Groundwater/Soil Gas Supplemental Limited Field Investigation Report. DOE/RL-95-99, Draft A, U.S. Department of Energy, Richland Operations Office, Richland, Washington.

Peterson, R. E., R. F. Raidl, and C. W. Denslow. 1996. Conceptual Site Models for Groundwater Contamination at 100-BC-5, 100-KR-4, 100-HR-3, and 100-FR-3 Operable Units. BHI-00917, Bechtel Hanford, Inc., Richland, Washington.

Sweeney, M. D. 2000a. Groundwater Sampling and Analysis Plan for the 100-BC-5 Operable Unit. PNNL-13326, Pacific Northwest National Laboratory, Richland, Washington.

Sweeney, M. D. 2000b. Groundwater Sampling and Analysis Plan for the 100-FR-3 Operable Unit. PNNL-13327, Pacific Northwest National Laboratory, Richland, Washington. 


\section{Distribution}

No. of

Copies

ONSITE

7 DOE Richland Operations Office

M. J. Furman (5)

Public Reading Room (2)

U.S. Environmental Protection Agency

D. A. Faulk

Bechtel Hanford, Inc.

P. G. Doctor
B5-01

A5-13

P8-55

B5-01

H0-23
No. of

Copies

Washington State Department of Ecology

W. W. Soper

B5-18

11 Pacific Northwest National Laboratory

C. J. Chou

K6-81

M. J. Hartman

K6-96

S. P. Luttrell

K6-96

M. D. Sweeney (5)

K6-81

D. Vela

K6-96

Hanford Technical Library (2) 